\title{
Design and Implementation of a Multiband Metamaterial-Loaded Reconfigurable Antenna for Wireless Applications
}

\author{
Ritesh Kumar Saraswat $\mathbb{D}^{1}$ and Mithilesh Kumar ${ }^{2}$ \\ ${ }^{1}$ M.L.V. Govt. Textile \& Engineering College, Bhilwara, Rajasthan, India \\ ${ }^{2}$ Rajasthan Technical University, Kota, Rajasthan, India \\ Correspondence should be addressed to Ritesh Kumar Saraswat; ritesh.saraswat9@gmail.com
}

Received 31 October 2021; Revised 30 November 2021; Accepted 2 December 2021; Published 13 December 2021

Academic Editor: Trushit Upadhyaya

Copyright (C) 2021 Ritesh Kumar Saraswat and Mithilesh Kumar. This is an open access article distributed under the Creative Commons Attribution License, which permits unrestricted use, distribution, and reproduction in any medium, provided the original work is properly cited.

\begin{abstract}
This article presents a multiband antenna with the implementation of a metamaterial split-ring resonator (SRR), quasicomplementary split-ring resonator (CSRR), and slots to achieve octaband characteristics for wireless standards. Multiband features are accomplished by the implementation of the slot approach within the radiating section part and loading the SRR and CSRR cells. The electrical dimension is $0.256 \lambda \times 0.176 \lambda \times 0.0128 \lambda\left(32 \times 22 \times 1.6 \mathrm{~mm}^{3}\right)$ of the proposed design, at a lower frequency of $2.4 \mathrm{GHz}$. The proposed design indicates the frequency-band reconfigurability nature by using the switching PIN diode placed at the slotted section of the ground plane. During the OFF state of switching, the element structure resonates in eight wireless communication bands covering various high-speed multiple applications of Internet of Things (IoT) regarding wireless standards S-band WLAN (WiFi, Bluetooth, Z-wave, wireless HART, and WBAN), lower C-band (WAIC, satellite communication transmission application), C-band WLAN, X-band (ITU region 2), Ku-band (direct broadcast satellite system and terrestrial microwave communication system service), and K-band (radar communication application) at 2.4, 4.3, 5.8, 8.5, 11.1, 13.9, 16.1, and $18.9 \mathrm{GHz}$, respectively, with $S_{11} \leq-10 \mathrm{~dB}$. The antenna achieves an optimum peak gain of $4.23 \mathrm{dBi}$ and radiation efficiency of $82.78 \%$ at operating frequency regarding wireless standards. The average efficiency of the proposed design is more than $70 \%$ for all resonant modes. The radiation characteristics (gain/efficiency/patterns/impedance matching) are shown in the stable and improved form at achieved wireless modes.
\end{abstract}

\section{Introduction}

In recent years, research has been focused on designing a wireless communication system with a multiband antenna because of its compactness in size, high data transmission rate, and low cost. It is very much required to combine multiband and miniaturization features within a single antenna design to operate multiple wireless applications. Antenna miniaturization and multiband configuration are achieved by using techniques such as the feeding approach [1-3], slotting approach [4-10], metamaterial cell insertion [11-17], and fractals [18]. The slot formation in the antenna design provides miniaturization and also multiple operating wireless standards due to the effect of current perturbation [19-21]. The multiband characteristics are also created by the implementation of the metamaterial cells (SRR/CSRR- negative permeability/permittivity characteristics). Various multiband antennas with metamaterial loading have also been reported in the last few years [22-24]. Sharma et al. [22] proposed a multiband antenna using a metamaterial loading technique to cover the WLAN/WiMAX applications. Also, a number of metamaterial-inspired antennas with multiple wireless communication bands have been reported [23-25]. A miniaturized quad-band antenna based on the fractal, slot, and metamaterial-inspired approach has been implemented [26]. In addition, there are several research activities focused on the reconfigurability characteristics with a metamaterialloaded multiband antenna [27, 28]. The antenna in [27] has size compactness with metamaterial structures and represents the reconfigurability for wireless standards. Multiband antenna performance with frequency-band reconfigurability is achieved by using a vertex-fed technique for an SRR- 
shaped structure [28]. In [28], an octagonal-shaped splitring resonator-based vertex-fed multiband antenna with a slotted ground plane in conjunction with a PIN diode (reconfigurability characteristics) is designed/analyzed to operate at six bands so as to attain various wireless standards. By selecting between the ON/OFF state of the PIN diode, the ground slots are electrically connected or disconnected. For simulation, the diode sets an ohmic resistance of $2.6 \Omega$ in the forward-biased state. On the other hand, the diode sets a capacitance of $0.16 \mathrm{pF}$ in the reversebiased state. Multiband antennas are proposed in [29, 30] for multiple wireless applications by employing the DGS (defected ground structure) and metamaterial loading schemes within antenna designs.

This article primarily focuses on antenna miniaturization regarding radiating area and antenna volume. Antenna miniaturization is achieved by inserting slotted SRR-based geometry (second iterative) inside the radiating patch area and reducing the dimensions of the design. Next, implementing the rectangular-shape quasicomplementary splitring resonator (CSRR) cell within the feedline and use of a split-ring resonator (SRR) with the trapezoidal shape slotted ground plane approach yielded operating bands $2.34-2.82 \mathrm{GHz} \quad(18.60 \%), \quad 3.84-4.53 \mathrm{GHz} \quad(16.49 \%)$, $5.61-5.985 \mathrm{GHz} \quad(6.47 \%), \quad 7.89-8.79 \mathrm{GHz} \quad(10.79 \%)$, $10.46-12.84 \mathrm{GHz} \quad(20.43 \%), \quad 13.84-14.50 \mathrm{GHz} \quad(4.66 \%)$, $15.69-17.37 \mathrm{GHz}(10.16 \%)$, and $18.21-19.86 \mathrm{GHz}(8.67 \%)$ during the simulation mode and $2.36-2.74 \mathrm{GHz}(14.90 \%)$, $3.92-4.42 \mathrm{GHz} \quad(11.99 \%), \quad 5.69-5.981 \mathrm{GHz} \quad(4.99 \%)$, 7.93-8.77 GHz (10.06\%), $\quad 10.52-12.68 \mathrm{GHz} \quad(18.62 \%)$, $13.89-14.42 \mathrm{GHz}(3.74 \%), 15.81-17.29 \mathrm{GHz}$ (8.94\%), and $18.22-19.64 \mathrm{GHz}(7.50 \%)$ under the measurement mode for IoT applications in wireless standards S-band WLAN, lower C-band, C-band WLAN (5.8 GHz-IEEE 802.11a), lower $\mathrm{X}$-band, upper X-band, lower Ku-band, upper Ku-band, and lower K-band, respectively. An RF PIN diode is employed at the place of an inverted $Z$-shaped slot of the ground plane regarding the frequency-band reconfigurability for wireless standards. In the OFF and ON states of the diode, the proposed design represents the octaband and pentaband behavior, respectively.

\section{Antenna Design and Configuration}

The proposed metamaterial-inspired multiband antenna with its design steps and S-parameter analysis is indicated in Figures 1-4, respectively. The antenna is implemented on an FR4 substrate with a dielectric constant of 4.4. The length, width, and thickness of the substrate on which the radiating element is printed are $32 \mathrm{~mm}, 22 \mathrm{~mm}$, and $1.6 \mathrm{~mm}$.

The antenna miniaturization with multiband operations is identified in the following design steps:

Design step-I: first, an octagonal-shape antenna with dimensions $35 \times 28 \times 1.6 \mathrm{~mm}^{3}$ is designed as depicted in Figure 1 (antenna configuration-“ $a$ "). This design represents the UWB operation with impedance bandwidth $11.11 \mathrm{GHz}(2.83-13.94 \mathrm{GHz}, 132.49 \%)$ in the simulation mode as illustrated in Figure 2. Antenna configuration- " $a$ " is miniaturized with respect to the antenna size and active patch area by the implementation of the slotted radiating part (four octagonalshaped conducting rings) and reduction of antenna dimensions (length and width), as shown in Figure 1 (antenna configuration- “ $b$ "). This miniaturized UWB antenna has dimensions $32 \times 22 \times 1.6 \mathrm{~mm}^{3}$ and an operating bandwidth of about $11.12 \mathrm{GHz}$ (2.85-13.97 GHz, $132.22 \%)$ during the simulation process, as represented in Figure 2. It is observed that both the antenna configurations " $a$ " and " $b$ " have almost equal operating bandwidth for UWB range, but the configuration " $b$ " exhibits the miniaturized form as compared to configuration " $a$." The miniaturization calculation regarding the active patch area and volume for antenna configuration " $b$ " as compared to configuration " $a$ " is analyzed in Table 1 . It is identified from Table 1 that the miniaturization is successfully achieved as per the design evolution from antenna configuration " $a$ " to " $b$."

Design step-II: by applying the etching process to create the single quasicomplementary split-ring resonator (CSRR) in the trapezoidal shape feedline, the triple-band characteristics $3.01-4.22 \mathrm{GHz}$ (S-band WiMAX), 4.97-6.28 GHz (C-band WLAN), 7.25-15.35 GHz (Xband), and 17.49-19.38 GHz (lower K-band) are derived for IoT-based wireless applications in design step-II, as depicted in Figures 3 and 4 (antenna configuration- “ $B$ "). The respective CSRR structure provides the current perturbation effect in the antenna structure to achieve the multiple resonating band (quadraband) features.

Design step-III: to achieve more multiple wireless standards, a slotted ground (S-shaped slot and rectangular slot on the ground plane) approach with a rectangular SRR cell is implemented, as illustrated in Figure 3 (antenna configuration- " $C$ and $D$ "). The etching of the rectangular and S-shaped slot on the ground plane and loading the SRR cell further affect the current distribution in the proposed design, thereby creating the antenna configuration- " $D$ " regarding octaband characteristics for IoT applications in wireless communication modes S-band WLAN (2.34-2.82 GHz: IEEE 802.11b-WiFi, Bluetooth, Zwave, wireless HART, and WBAN), lower C-band (3.84-4.53 GHz: WAIC, avionic satellite communication transmission application), C-band WLAN (5.61-5.985 GHz: IEEE 802.11a), lower X-band (7.89-8.79 GHz: Earth exploration-satellite service ITU region 2), upper X-band (10.46-12.84 GHz: amateur radio satellite operating band), lower $\mathrm{Ku}$-band (13.84-14.50 GHz: direct broadcast satellite system), upper $\mathrm{Ku}$-band (15.69-17.37 GHz: terrestrial microwave communication system service), and lower K-band (18.21-19.86 GHz: radar communication application) wireless standards, as shown in Figures 3 and 4. By placing the single SRR structure with a slotted ground plane, two narrow resonant bands at 2.42 and $5.81 \mathrm{GHz}$ for S-band and C-band WLAN, respectively, 

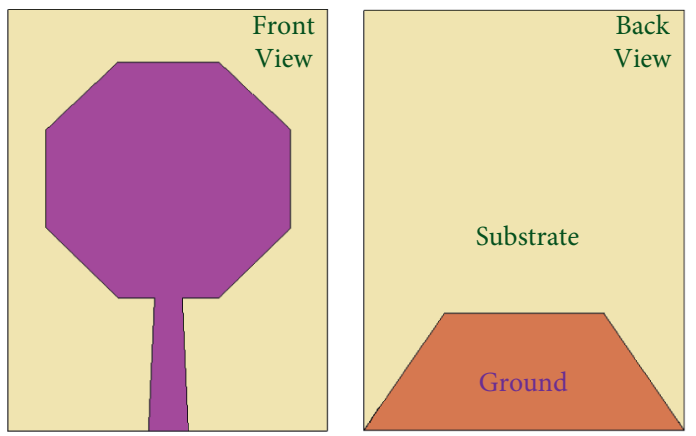

(a)
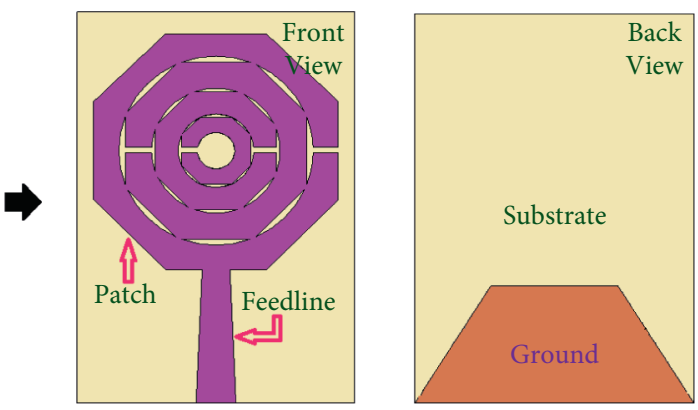

(b)

FIGURE 1: Design step of the proposed miniaturized single-band (UWB) antenna.

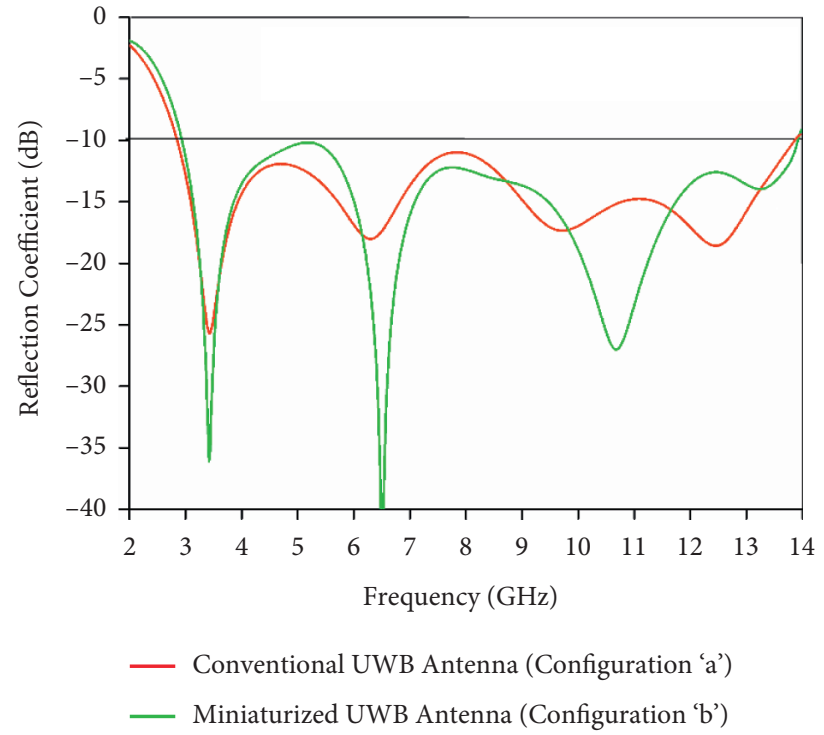

FIGURE 2: $S_{11}$ (Sim.) of the miniaturized single-band (UWB) antenna for design step-I.

are obtained. The solenoidal conducting current is present inside the SRR branches to produce the magnetic effect regarding negative permeability features. In order to make the reconfigurability nature, a PIN diode is placed inside the S-shaped slot at the ground plane (Figure 3: antenna configuration- “ $D$ ") and the penta-/octaband configuration during $\mathrm{ON} /$ OFF states of the PIN diode, respectively, is accomplished, as depicted in Figure 5. The biasing condition (ON/OFF states) generates the current perturbation phenomenon in the structure to achieve the reconfiguration mode [27, 28].

The top, side, and bottom layouts (as per design stepIII: antenna configuration- " $D$ ") of the proposed antenna are further illustrated in Figure 6 . The proposed antenna has a compact size of $32 \times 22 \times 1.6 \mathrm{~mm}^{3}$ with a slotted octagonal-shape radiating patch fed by a trapezoidal-shape feedline $\left(Z_{o}=50 \Omega\right)$, single quasi-CSRR (etched inside the feedline) and slotted ground loaded with a rectangular SRR cell. The optimized parametric dimensions (in $\mathrm{mm}$ ) are mentioned in Table 2.
The antenna is simulated and characterized using the finite-element-based electromagnetic solver, CST Microwave Studio (MWS) [31]. The top and rear view of the fabricated antenna are shown in Figure 7.

The application of DC potential at the metallic strip (dimension of $2 \times 0.6 \mathrm{~mm}^{2}$, as shown in Figure 6(c)) for the biasing of PIN diodes affects the RF current and offers another path for the RF current to flow. The arrangement of the diode, strip, and blocking capacitor $(100 \mathrm{pF})$ is set up in a series formation and established at the slotted ground section. The use of a blocking capacitor is to generate the isolation effect for the RF signal from the DC part. The reconfiguration mechanism is performed by using a beam lead PIN diode (ALPHA-6355) according to the DC potential $(0.7 \mathrm{~V})$ applied. The frequency-band reconfigurability characteristics depend on the diode switching; in forward bias (ON state), the diode works as a series combination of resistance $R_{\mathrm{CCF}}=2.6 \Omega$ and inductance $L_{\mathrm{FR}}=0.6 \mathrm{nH}$, and in reverse bias (OFF state), it works as a parallel combination of capacitance $C_{\mathrm{RE}}=0.081 \mathrm{pF}$ and resistance $R_{\mathrm{CCR}}=5 \mathrm{k} \Omega$ with a series inductance of $0.6 \mathrm{nH}$ [32], as depicted in the equivalent model in Figures 8(a) and 8(b). 

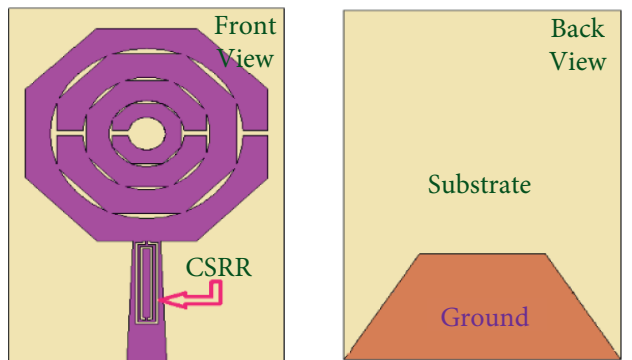

(b)
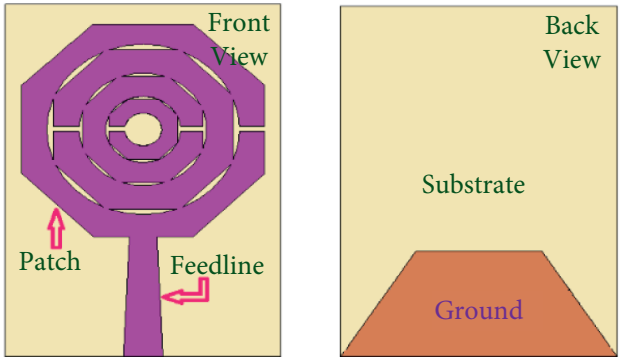

(a)
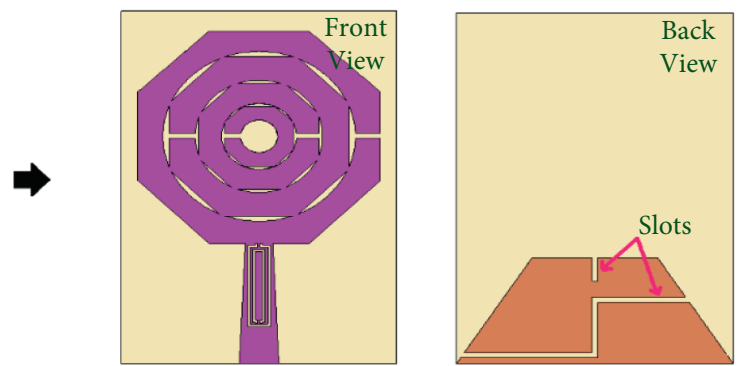

(c)
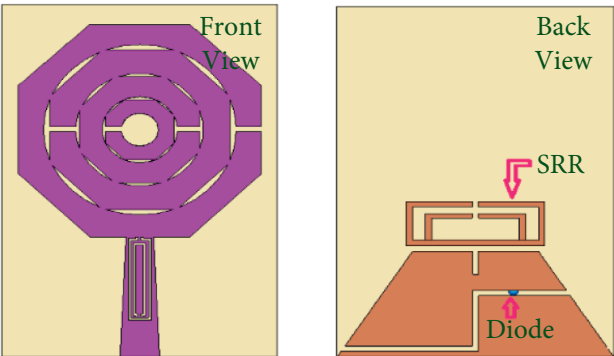

(d)

Figure 3: Design stages of the proposed miniaturized multiband antenna.

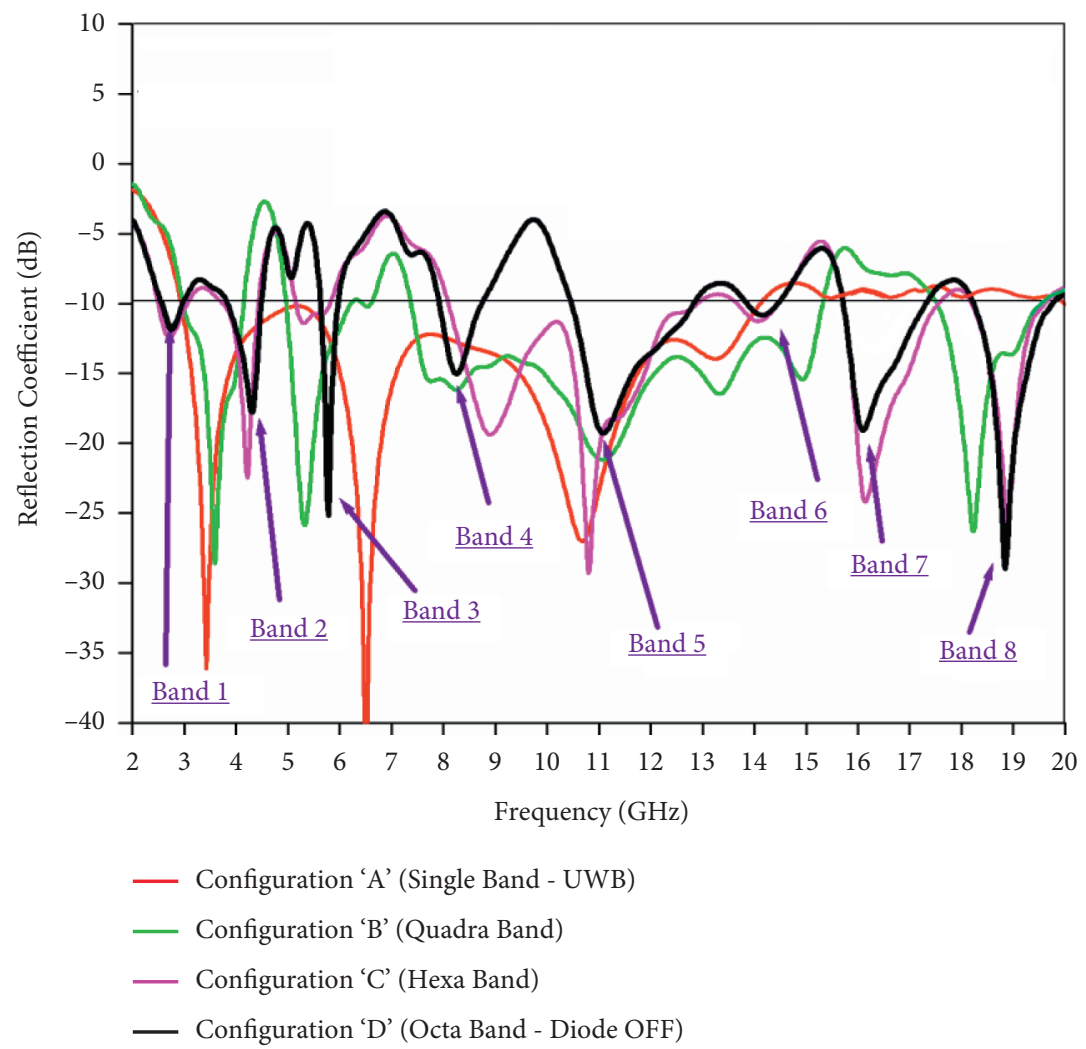

FIGURE 4: $S_{11}$ (Sim.) of the proposed miniaturized multiband antenna.

An experimental observation of various parameters of the proposed antenna is performed by using a vector network analyzer (VNA) on an anechoic chamber, as illustrated in Figure 9. When the PIN diode is in the ON condition, the antenna radiates with five (penta) operating bands, whereas during the OFF state of the diode, it resonates over eight 
TABLE 1: Miniaturization observation in the proposed design.

\begin{tabular}{|c|c|c|c|}
\hline Design step-antenna configuration & Dimensions (in $\mathrm{mm}^{3}$ ) & Active radiating patch area (in $\mathrm{mm}^{2}$ ) & $\begin{array}{l}\text { Total volume } \\
\left(\text { in } \mathrm{mm}^{3} \text { ) }\right.\end{array}$ \\
\hline “a” & $35 \times 28 \times 1.6$ & 309.02 & 1568 \\
\hline “b” & $32 \times 22 \times 1.6$ & 274.13 & 1126.4 \\
\hline $\begin{array}{l}\text { Miniaturization achieved for antenna during the UWB mode } \\
\text { (in \%) }\end{array}$ & & 11.29 & 28.16 \\
\hline
\end{tabular}
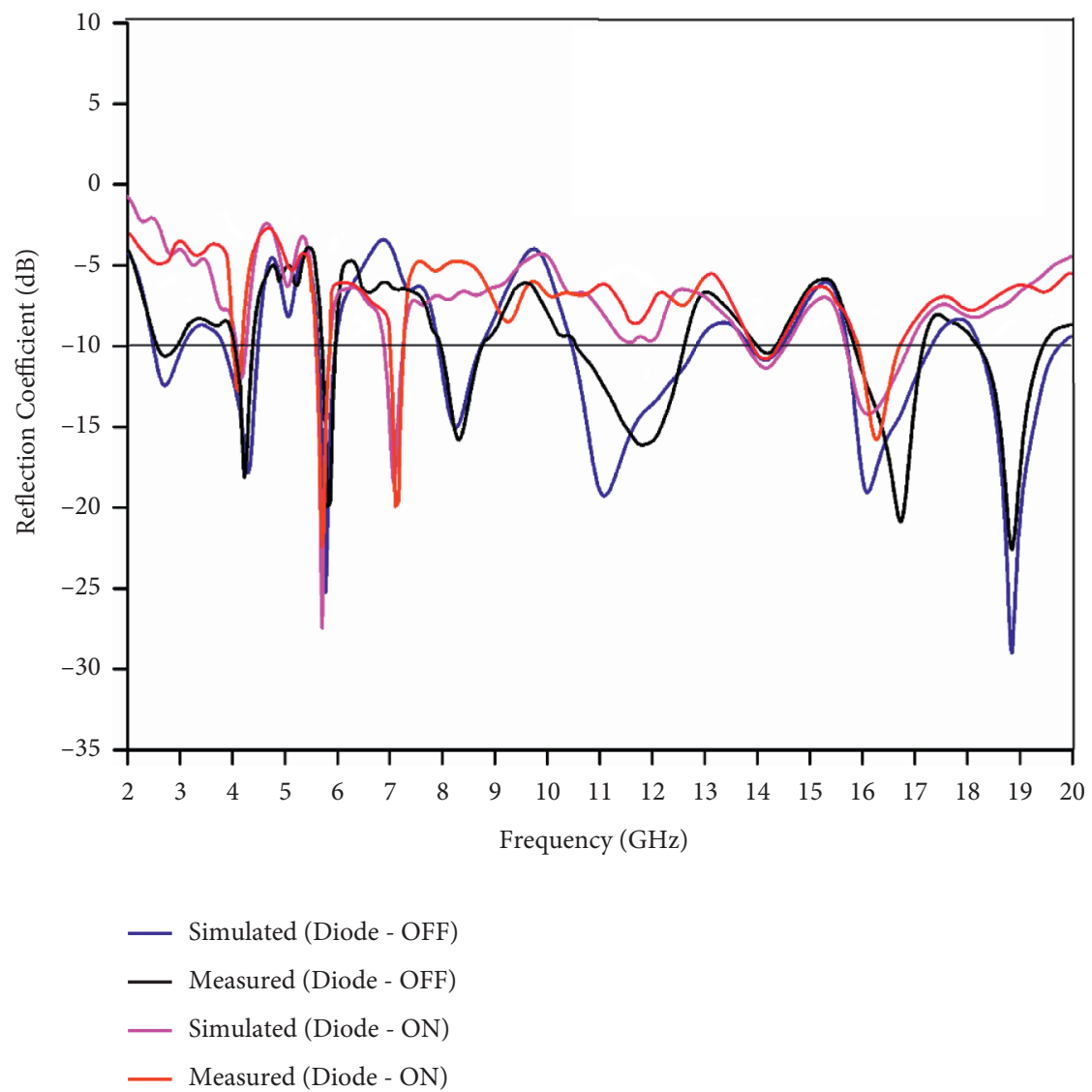

Figure 5: $S_{11}$ (Sim. and Meas.) during biasing modes of the diode.

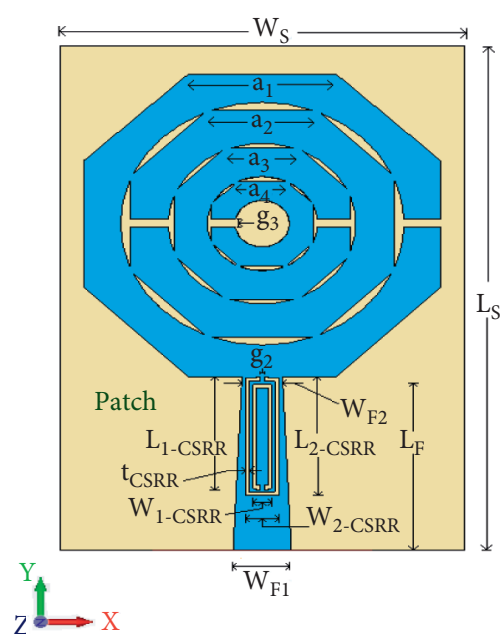

(a)

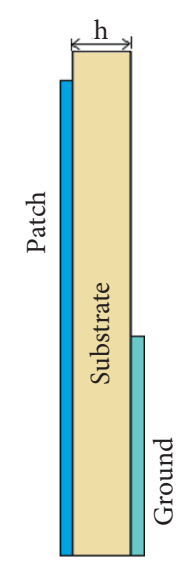

(b)

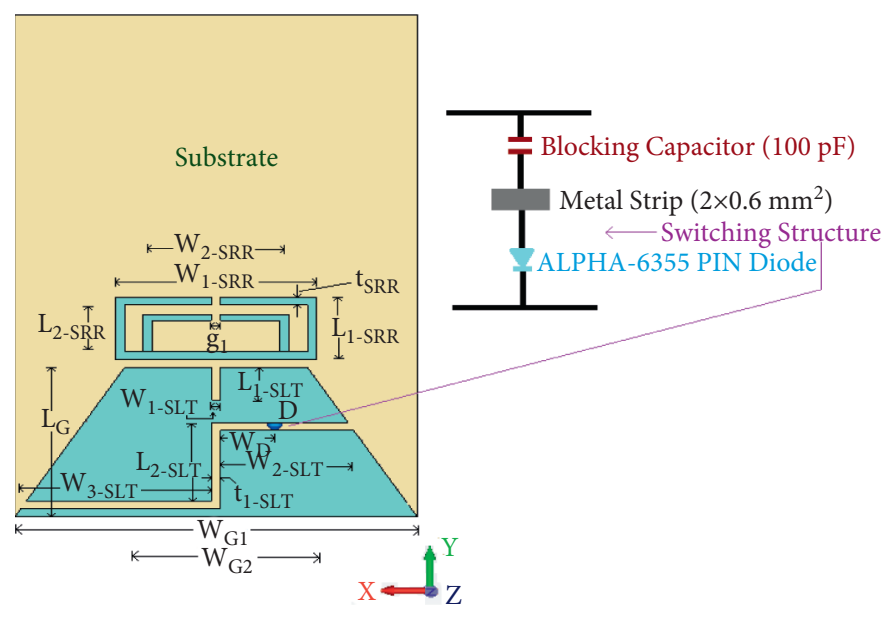

(c)

Figure 6: Miniaturized multiband antenna: (a) upper section, (b) side section, and (c) bottom section. 
TABle 2: Antenna optimized dimensions (in $\mathrm{mm}$ ).

\begin{tabular}{|c|c|c|c|c|c|c|c|c|c|c|}
\hline$L_{S}$ & $W_{S}$ & $h$ & $a_{1}$ & $a_{2}$ & $a_{3}$ & $a_{4}$ & $L_{F}$ & $W_{f 1}$ & $W_{f 2}$ & $t_{\mathrm{SRR}}$ \\
\hline 32 & 22 & 1.6 & 8 & 6 & 4 & 2.5 & 11 & 3.16 & 2.2 & 0.5 \\
\hline$g_{3}$ & $L_{1-\mathrm{CSRR}}$ & $L_{2-\mathrm{CSRR}}$ & $W_{1-\mathrm{CSRR}}$ & $W_{2-\mathrm{CSRR}}$ & $t_{\mathrm{CSRR}}$ & $g_{2}$ & $L_{G}$ & $W_{G 1}$ & $W_{G 2}$ & $g_{1}$ \\
\hline $\begin{array}{l}0.5 \\
L_{1-\mathrm{SLT}}\end{array}$ & $\begin{array}{c}6.6 \\
W_{1-\mathrm{SLT}}\end{array}$ & $\begin{array}{c}7.4 \\
L_{2-S L T}\end{array}$ & $\begin{array}{c}1 \\
W_{2-\mathrm{SLT}}\end{array}$ & $\begin{array}{c}1.8 \\
W_{3-\mathrm{SLT}}\end{array}$ & $\begin{array}{c}0.2 \\
t_{1-\mathrm{SLT}}\end{array}$ & $\begin{array}{c}0.2 \\
L_{1-\mathrm{SRR}}\end{array}$ & $\begin{array}{c}9.5 \\
L_{2-\mathrm{SRR}}\end{array}$ & $\begin{array}{c}22 \\
W_{1-\mathrm{SRR}}\end{array}$ & $\begin{array}{c}10 \\
W_{2-\mathrm{SRR}}\end{array}$ & $\begin{array}{c}0.5 \\
W_{D}\end{array}$ \\
\hline 2 & 0.5 & 5 & 7 & 10 & 0.5 & 4 & 3 & 11 & 10 & 3 \\
\hline
\end{tabular}

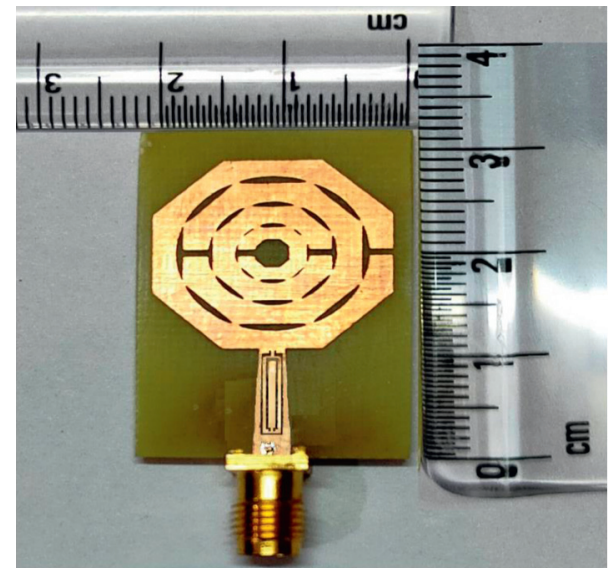

(a)

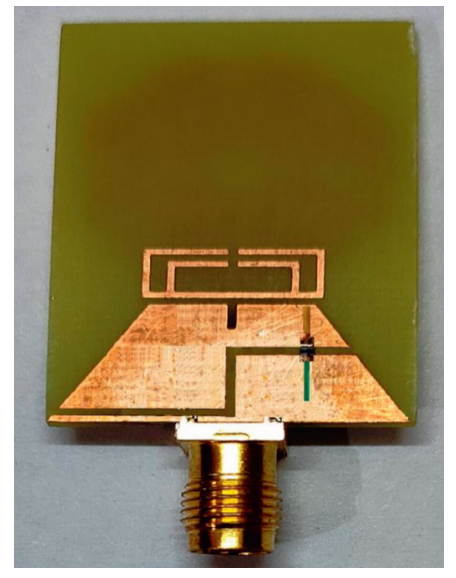

(b)

Figure 7: Printed prototype: (a) top section; (b) rear section.

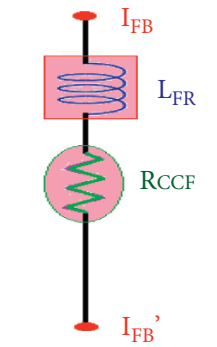

Forward Bias (ON State)

(a)

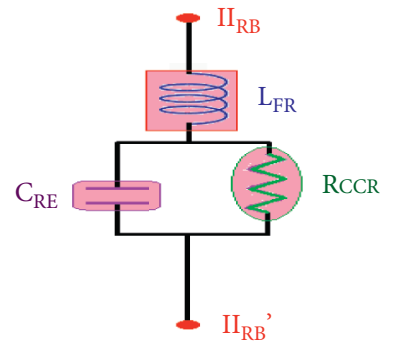

Reverse Bias (OFF State)

(b)

FIgURE 8: Equivalent model RF PIN diode.

(octa) operating bands due to the variation in the electrical current path length, as indicated in Figure 5 and mentioned in Table 3. The proposed design has octaband characteristics (OFF state of the PIN diode) with an $S_{11}<-10 \mathrm{~dB}$ impedance bandwidth of about $480 \mathrm{MHz}(2.34-2.82 \mathrm{GHz}, 18.60 \%)$, $690 \mathrm{MHz} \quad(3.84-4.53 \mathrm{GHz}, \quad 16.49 \%), \quad 375 \mathrm{MHz}$ (5.61-5.985 GHz, $\quad 6.47 \%), \quad 900 \mathrm{MHz} \quad(7.89-8.79 \mathrm{GHz}$, $10.79 \%), 2380 \mathrm{MHz}(10.46-12.84 \mathrm{GHz}, 20.43 \%), 660 \mathrm{MHz}$ $(13.84-14.50 \mathrm{GHz}, \quad 4.66 \%), \quad 1680 \mathrm{MHz} \quad(15.69-17.37 \mathrm{GHz}$, $10.16 \%)$, and $1.65 \mathrm{GHz}(18.21-19.86 \mathrm{GHz}, 8.67 \%)$ under the simulation process and $14.90 \%(2.36-2.74 \mathrm{GHz}), 11.99 \%$ $(3.92-4.42 \mathrm{GHz}), \quad 4.99 \% \quad(5.69-5.981 \mathrm{GHz}), \quad 10.06 \%$ $(7.93-8.77 \mathrm{GHz}), \quad 18.62 \% \quad(10.52-12.68 \mathrm{GHz}), \quad 3.74 \%$ $(13.89-14.42 \mathrm{GHz}), \quad 8.94 \%(15.81-17.29 \mathrm{GHz})$, and $7.50 \%$ $(18.22-19.64 \mathrm{GHz})$ during the experimental process, as shown in Figure 5. The frequency reconfiguration of the proposed structure regarding wireless communication modes is achieved by simultaneous biasing of the switching element diode, as given in Table 3.

2.1. Parametric Investigation. The optimal designing constraints and dimensions of the proposed design are achieved by using the parametric analysis with respect to feedline widths $\left(W_{f 1}\right.$ and $\left.W_{f 2}\right)$ and ground dimensions $\left(L_{G}\right.$ and $W_{G 2}$ ). The comparison graph of the $S_{11}$ parameter is observed for different values of feedline $W_{f 1}(2,3,3.16$, and $4 \mathrm{~mm})$ and $W_{f 2}(1.8,2.0,2.2,2.5$, and $3.0 \mathrm{~mm})$, as depicted in Figure 10. It is clear from the graph that optimum feedline widths $W_{f 1}$ and $W_{f 2}$ which could give significant antenna response are $3.16 \mathrm{~mm}$ and $2.2 \mathrm{~mm}$, respectively, which is shown by the black color line in Figure 10. By optimizing the 


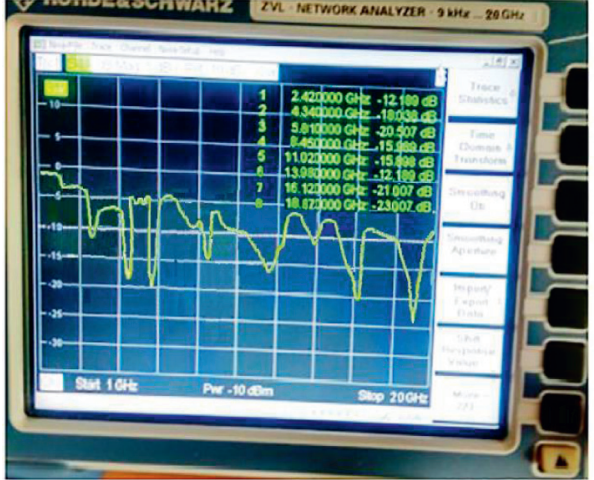

(a)

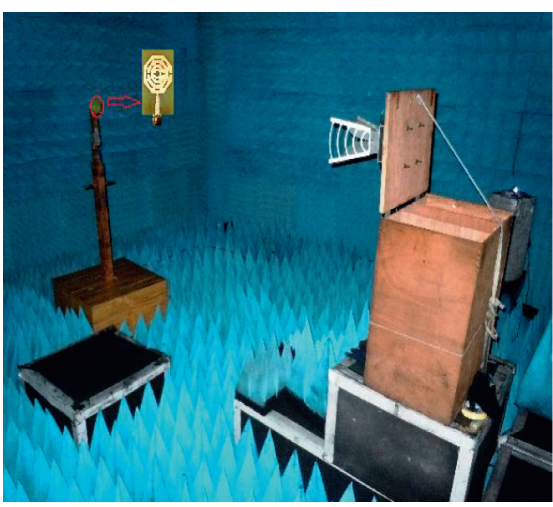

(b)

FIGURE 9: Measurement arrangement for the proposed multiband antenna.

TABLE 3: Frequency reconfiguration states of the proposed design.

\begin{tabular}{|c|c|c|c|c|c|c|c|c|c|}
\hline \multirow{2}{*}{$\begin{array}{l}\text { PIN diode } \\
\text { biasing } \\
\text { modes }\end{array}$} & \multicolumn{2}{|c|}{ Impedance bandwidth (in $\mathrm{GHz}$ ) } & \multicolumn{2}{|c|}{$\begin{array}{c}S_{11}<-10 \mathrm{~dB} \\
\text { fractional } \\
\text { bandwidth (in \%) }\end{array}$} & \multicolumn{2}{|c|}{ Gain $(\mathrm{dBi})$} & \multicolumn{2}{|c|}{ Efficiency (\%) } & \multirow[t]{2}{*}{ Applications covered } \\
\hline & Sim. & Meas. & Sim. & Meas. & Sim. & Meas. & Sim. & Meas. & \\
\hline $\begin{array}{l}\text { Forward } \\
\text { bias (ON } \\
\text { state) }\end{array}$ & $\begin{array}{c}4.01-4.42 / \\
5.51-5.92 / \\
6.89-7.31 / \\
13.79-14.57 / \\
15.67-16.92\end{array}$ & $\begin{array}{c}4.10-4.41 / \\
5.54-5.90 / \\
6.92-7.27 / \\
13.83-14.49 / \\
15.78-16.88\end{array}$ & $\begin{array}{l}9.73 / \\
7.17 / \\
5.91 / \\
5.50 / \\
7.67\end{array}$ & $\begin{array}{l}7.28 / \\
6.29 / \\
4.93 / \\
4.66 / \\
6.74\end{array}$ & $\begin{array}{l}2.02 / \\
2.98 / \\
2.76 / \\
2.55 / \\
3.01\end{array}$ & $\begin{array}{l}1.98 / \\
2.04 / \\
2.10 / \\
1.99 / \\
2.79\end{array}$ & $\begin{array}{l}52.78 / \\
68.82 / \\
67.91 / \\
72.71 / \\
79.26\end{array}$ & $\begin{array}{l}47.12 / \\
55.27 / \\
54.34 / \\
69.23 / \\
71.92\end{array}$ & $\begin{array}{c}\text { No. of applications-5 } \\
\text { (IoT application-lower C- } \\
\text { band-4.3 GHz, WAIC, } \\
\text { avionic satellite } \\
\text { communication } \\
\text { transmission application/ } \\
\text { C-band WLAN-5.8 GHz, } \\
\text { IEEE } 802.11 \mathrm{a} / \text { upper C- } \\
\text { band } 7.01 \mathrm{GHz} \text {, INSAT } \\
\text { communication system/ } \\
\text { lower Ku- } \\
\text { band-13.9 GHz, direct } \\
\text { broadcast satellite system/ } \\
\text { upper Ku- } \\
\text { band-16.1 GHz, and } \\
\text { terrestrial microwave } \\
\text { communication system } \\
\text { service) }\end{array}$ \\
\hline
\end{tabular}


TABLE 3: Continued.

\begin{tabular}{|c|c|c|c|c|c|c|c|c|c|}
\hline \multirow[t]{2}{*}{$\begin{array}{l}\text { PIN diode } \\
\text { biasing } \\
\text { modes }\end{array}$} & \multicolumn{2}{|c|}{ Impedance bandwidth (in $\mathrm{GHz}$ ) } & \multicolumn{2}{|c|}{$\begin{array}{c}S_{11}<-10 \mathrm{~dB} \\
\text { fractional } \\
\text { bandwidth (in \%) }\end{array}$} & \multicolumn{2}{|c|}{ Gain $(\mathrm{dBi})$} & \multicolumn{2}{|c|}{ Efficiency (\%) } & \multirow[t]{2}{*}{ Applications covered } \\
\hline & Sim. & Meas. & Sim. & Meas. & Sim. & Meas. & Sim. & Meas. & \\
\hline $\begin{array}{l}\text { Reverse } \\
\text { bias (OFF } \\
\text { state) }\end{array}$ & $\begin{array}{c}2.34-2.82 / \\
3.84-4.53 / \\
5.61-5.985 / \\
7.89-8.79 / \\
10.46-12.84 / \\
13.84-14.50 / \\
15.69-17.37 / \\
18.21-19.86\end{array}$ & $\begin{array}{c}2.36-2.74 / \\
3.92-4.42 / \\
5.69-5.981 / \\
7.93-8.77 / \\
10.52-12.68 / \\
13.89-14.42 / \\
15.81-17.29 / \\
18.22-19.64\end{array}$ & $\begin{array}{c}18.60 / \\
16.49 / \\
6.47 / \\
10.79 / \\
20.43 / \\
4.66 / \\
10.16 / \\
8.01\end{array}$ & $\begin{array}{c}14.90 / \\
11.99 / \\
4.99 / \\
10.06 / \\
18.62 / \\
3.74 / \\
8.94 / \\
7.50\end{array}$ & $\begin{array}{l}2.31 / \\
2.67 / \\
2.98 / \\
2.49 / \\
3.84 / \\
2.29 / \\
3.61 / \\
4.23\end{array}$ & $\begin{array}{l}1.98 / \\
2.01 / \\
2.67 / \\
2.12 / \\
2.98 / \\
1.98 / \\
3.08 / \\
3.84\end{array}$ & $\begin{array}{c}68.24 / \\
62.43 / \\
79.84 / \\
78.91 / \\
81.02 / \\
61.12 / \\
78.84 / \\
81.78\end{array}$ & $\begin{array}{l}65.12 / \\
49.89 / \\
71.86 / \\
69.81 / \\
73.56 / \\
58.79 / \\
71.62 / \\
78.92\end{array}$ & $\begin{array}{c}\text { No. of applications-8 } \\
\text { (IoT application-S-band } \\
\text { WLAN } 2.4 \mathrm{GHz}, \mathrm{WiFi} \text {, } \\
\text { bluetooth, } Z \text {-wave, wireless } \\
\text { HART, WBAN/IoT } \\
\text { application-lower C- } \\
\text { band-4.3 GHz, WAIC, } \\
\text { avionic satellite } \\
\text { communication } \\
\text { transmission application/ } \\
\text { C-band WLAN-5.8 GHz, } \\
\text { IEEE } 802.11 \mathrm{a} / \text { lower X- } \\
\text { band-8.5 GHz, ITU } \\
\text { region } 2 / \text { upper X- } \\
\text { band- } 11.1 \mathrm{GHz} \text {, amateur } \\
\text { radio satellite operating } \\
\text { band/lower Ku- } \\
\text { band-13.9 GHz, direct } \\
\text { broadcast satellite system/ } \\
\text { upper Ku- } \\
\text { band-16.1 GHz, } \\
\text { terrestrial microwave } \\
\text { communication system } \\
\text { service/lower K- } \\
\text { band-18.9 GHz, and } \\
\text { radar communication } \\
\text { application) }\end{array}$ \\
\hline
\end{tabular}

appropriated feedline widths, the structure could have better impedance matching which may lead the antenna to noteworthy output at claimed frequencies. Another observation is that the impedance matching is improved either when the feedline widths are increased for a lower frequency range $\left(W_{f 1}: 2\right.$ to $7 \mathrm{GHz} ; W_{f 2}: 2$ to $\left.9 \mathrm{GHz}\right)$ or when the feedline widths are reduced regarding a higher operating range ( $W_{f 1}$ and $W_{f 2}: 10$ to $20 \mathrm{GHz}$ ).

The next part of the parametric study is involved with the investigation of antenna performance related to various values of ground dimensions (length $L_{G} 7.5,8.5,9.5,10.5$, and $11.5 \mathrm{~mm}$ and width $W_{G 2} 8,9,10,11$, and $12 \mathrm{~mm}$ ). The significant antenna performance regarding $S_{11}$ is utilized at $L_{G}=9.5 \mathrm{~mm}$ and $W_{G 2}=10 \mathrm{~mm}$, as indicated by the black color line in Figure 11. It is noticed that the operating-band characteristics of the proposed design are varying for different values of ground dimensions. From Figure 11, it can be seen that, by increasing the parametric values of the ground dimensions $\left(L_{G}\right.$ and $\left.W_{G 2}\right)$, the number of resonant bands with improved impedance matching is achieved. At a lower-frequency region (under $11 \mathrm{GHz}$ ), antenna performance $\left(S_{11}\right.$ parameter-impedance matching) is enhanced when the values of ground length $L_{G}$ and width $W_{G 2}$ are decreased, whereas at a higher frequency range (above $11 \mathrm{GHz}$ ), the antenna achieved the multiband features with improved resonant characteristics when the values of ground length $L_{G}$ and width $W_{G 2}$ are increased.
The optimized parameters regarding radiating patches are observed after carrying out rigorous parametric analysis of patch dimensions. An increase in branch length $\left(a_{1}\right)$ and split gap $\left(g_{3}\right)$ of the radiating patch causes reduction in resonance, as apparent from Figure 12. The optimum values of $8 \mathrm{~mm}$ and $0.5 \mathrm{~mm}$ are fixed for patch branch length $\left(a_{1}\right)$ and split gap $\left(g_{3}\right)$, respectively, to support the applications. It is also observed that the antenna resonant characteristics are improved at a lower frequency range (less than $9 \mathrm{GHz}$ ) when the values of patch branch length $\left(a_{1}\right)$ and split gap $\left(g_{3}\right)$ are reduced, whereas at a higher frequency range (above $9 \mathrm{GHz}$ ), the antenna represents the enhanced performance when the values of patch branch length $\left(a_{1}\right)$ and split gap $\left(g_{3}\right)$ are increased.

After the optimized parameters of feedline, ground, and patch are determined, the critical parameters of the complementary split-ring resonator (CSRR) are chosen based on the parametric analysis. The parameter is chosen for the analysis CSRR dimensions (Length $-L_{2 \text {-CSRR }}$ and width $\left.-W_{2 \text {-CSRR }}\right)$. The value of length $\left(L_{2 \text {-CSRR }}\right)$ and width $\left(W_{2 \text {-CSRR }}\right)$ is increased in steps of 0.1 and $0.2 \mathrm{~mm}$ from 7.3 to $7.6 \mathrm{~mm}$ and 1.6 to $2.2 \mathrm{~mm}$, respectively. The analysis is presented in Figure 13, and we observe that $L_{2}$ CSRR $=7.4 \mathrm{~mm}$ and $W_{2 \text {-CSRR }}=1.8 \mathrm{~mm}$ have good impedance matching in all the resonating bands. Finally, the parametric studies provide the best performance of the proposed design 

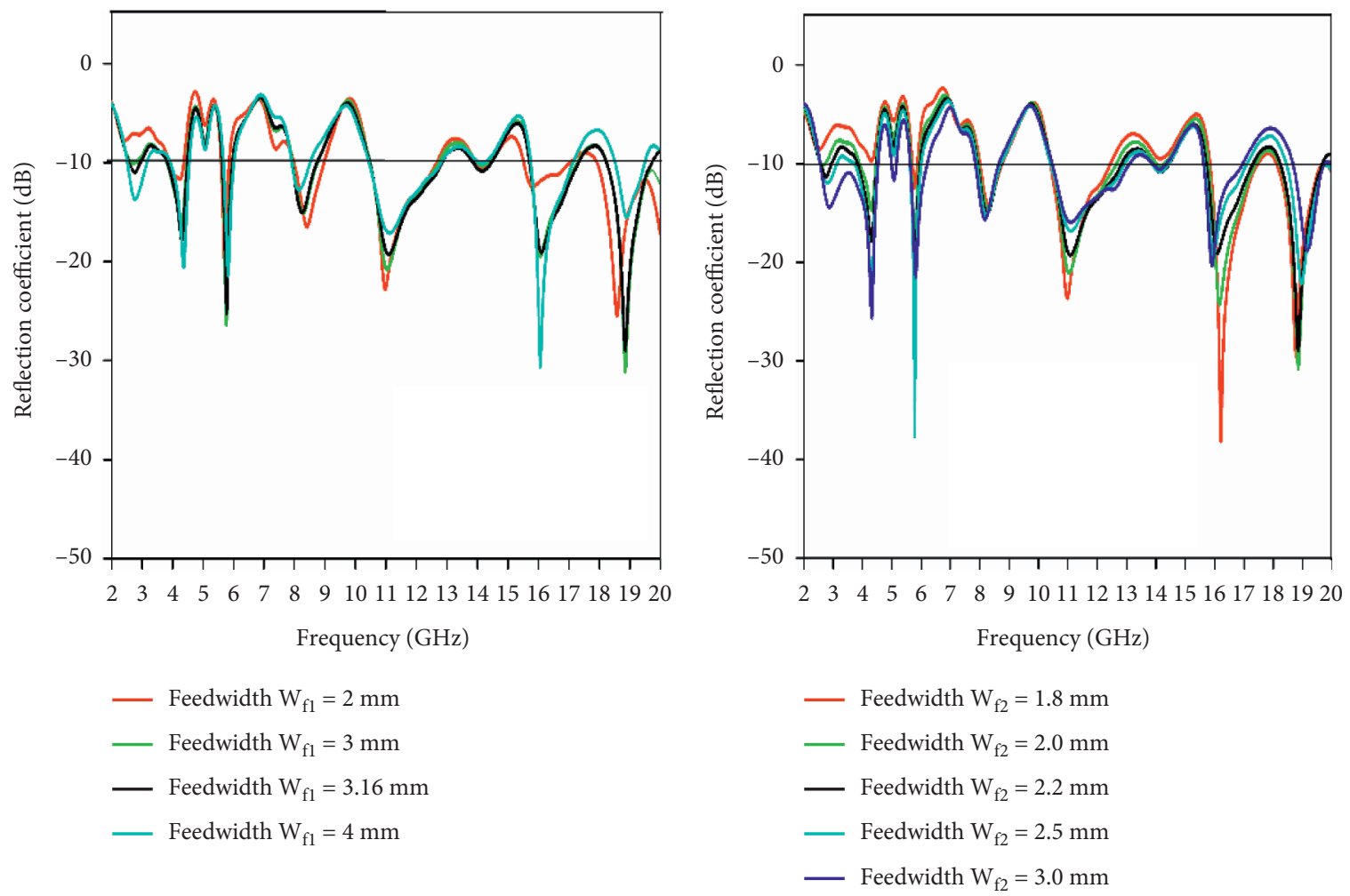

FIgURE 10: Comparison of antenna performance for different values of feedline widths $W_{f 1}$ and $W_{f 2}$.
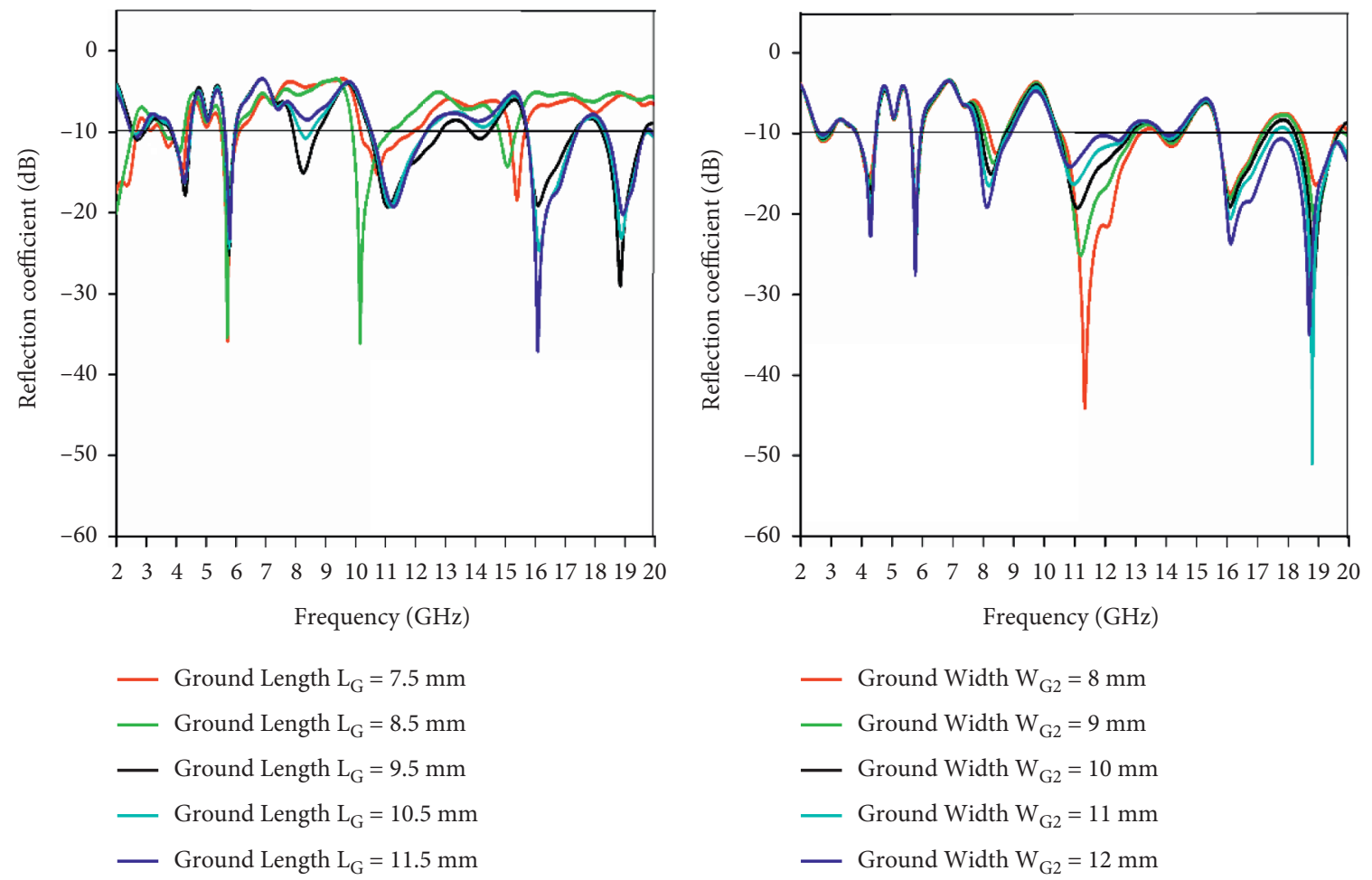

FIGURE 11: Comparison of antenna performance for different values of ground dimensions $L_{G}$ and $W_{G 2}$.

with the help of comparative analysis of the $S$-parameter $\left(S_{11}\right)$ for different values of feedline widths and ground dimensions.
2.2. Design Methodology of the Proposed Metamaterial SRR Structure. This section covers the design process and analysis of the proposed metamaterial SSR unit cell. The 

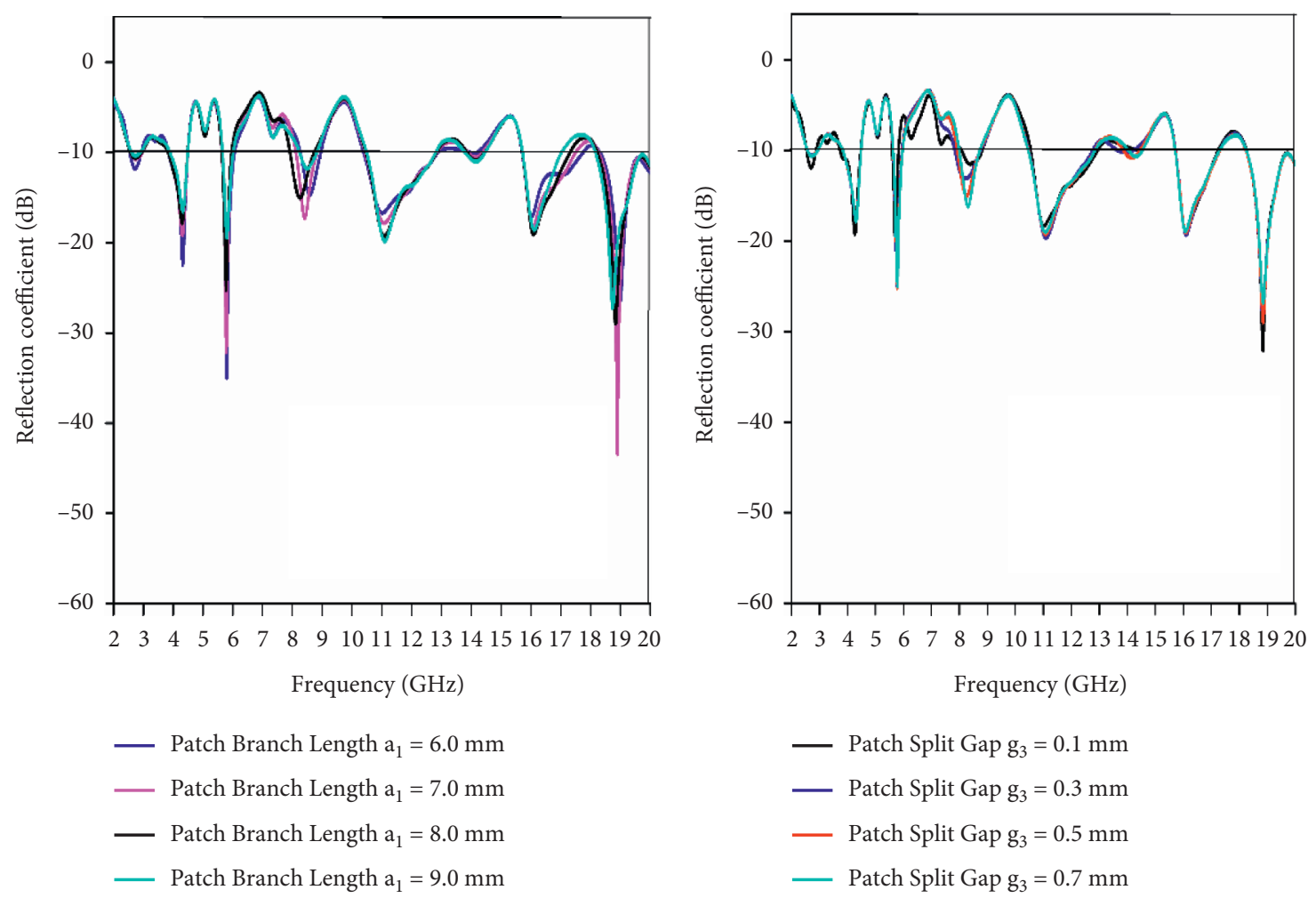

FIGURE 12: Comparison of antenna performance for different values of patch dimensions branch length $\left(a_{1}\right)$ and gap $\left(g_{3}\right)$.
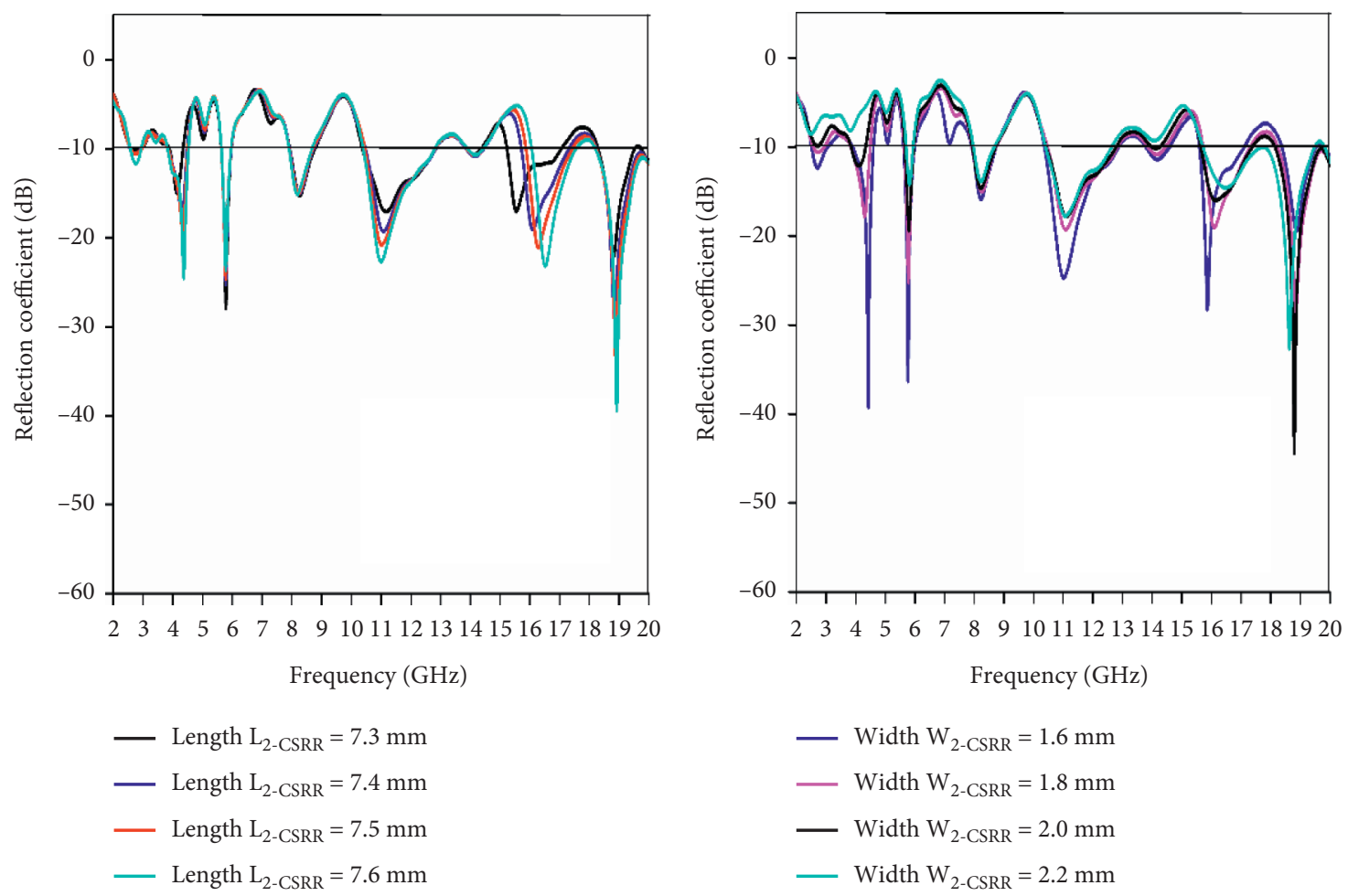

FIGURE 13: Comparison of antenna performance for different values of CSRR dimensions length $\left(L_{2 \text {-CSRR }}\right)$ and width $\left(W_{2 \text {-CSRR }}\right)$.

proposed SRR structure is designed with the implementation of two modified rectangular-shape conducting material resonating rings with a split gap. The permeability/ permittivity characteristics of the proposed structure are attained with the help of a waveguide setup, as depicted in Figure 14. The waveguide setup provides the $S$-parameters 
$\left(S_{11}\right.$ and $\left.S_{21}\right)$ to obtain the effective dielectric constants $\left(\mu_{\text {eff }}\right.$ and $\left.\varepsilon_{\text {eff }}\right)$ of the metamaterial SRR cell. This setup is realized in the simulated formation by using a CST Microwave Studio (MWS) simulator, as indicated in Figure 14(a). Figure 14(b) represents the electrical equivalent model of the proposed SRR cell, consisting of the parallel and series combination of distributed/gap capacitance, inductance, and resistance, respectively [31]. An experimental waveguide setup is formed by placing the SRR structure inside it, and the parameters are measured $\left(S_{11}\right.$ and $\left.S_{21}\right)$ with the help of VNA [33].

During the simulated waveguide setup, the external magnetic $(H)$ field is processed towards the SRR cell by which EMF is created around the cell and coupled across the rectangular conducting rings. Afterward, the conducting current is moved from the outside conducting ring to the inner side ring through the ring's gap (" $g_{1}$ "), which is liable to generate the capacitive effect (distributed capacitance). This arrangement originates in the LC resonant environment, and the respective operating frequency $\left(f_{\text {reso-SRR }}\right)$ is identified by the following equation [34]:

$$
f_{\text {reso-SRR }}=\frac{1}{2 \pi \sqrt{L_{\text {tot-equv }} C_{\text {tot-equv }}}} .
$$

The total equivalent inductance and capacitance are determined by using the following equations:

$$
\begin{aligned}
& L_{\text {tot-equv }}=0.0002\left[\left\{2\left(L_{\text {Extrn-SRR }}+W_{\text {Exten-SRR }}\right)-g_{1}\right\}\left\{\left(\log _{e} 8\right) \frac{\left(L_{\text {Extrn-SRR }}+W_{\text {Exten-SRR }}-0.5 g_{1}\right)}{t_{\text {SRR }}}\right\}-Q\right], \\
& C_{\text {tot-equv }}=0.5\left[\left\{\left(L_{\text {Extrn-SRR }}+W_{\text {Exten-SRR }}\right)-\pi\left(t_{\text {SRR }}+0.5 g^{\prime}\right)-g_{1}\right\}\left\{\left(0.3 \times 10^{-8}\right)\left(\frac{\sqrt{\varepsilon_{e}}}{Z_{0}}\right)\right\}+\left\{\frac{\left(8.85 \times 10^{-12}\right) h^{\prime} t_{\text {SRR }}}{\left.g_{1}\right\}},\right.\right.
\end{aligned}
$$

where $L_{\text {Extrn-SRR }}=$ length (external rectangular SRR ring), $W_{\text {Extrn-SRR }}=$ width (external rectangular SRR ring), $g_{1}=$ split gap, $t_{\mathrm{SRR}}=$ thickness, $Q=$ constant $(2.4512), g^{\prime}=$ rectangular SRR ring's gap, $\varepsilon_{e}=$ effective permittivity of the medium, $Z_{0}=$ characteristic impedance, and $h^{\prime}=$ height of the conducting strip.
The following equations are implemented to achieve the effective medium parameter (permeability- $\mu_{\text {eff-med-par }}$ ) of the proposed SRR [34, 35]:

$$
\mu_{\text {eff-med-par }}=n_{\text {ref-ind }} \times z_{\text {imp }}
$$

where

$$
\begin{aligned}
\operatorname{Refractive} \text { index }\left(n_{\text {ref-ind }}\right) & =\left(\frac{1}{k_{\mathrm{wn}} P_{\text {slab }}}\right) \cos ^{-1}\left[\left(\frac{0.5}{S_{21}}\right)\left\{\left(S_{21}\right)^{2}-\left(S_{11}\right)^{2}+1\right\}\right] \\
\text { Impedance }\left(z_{\text {imp }}\right) & =\left[\frac{\left\{\left(1+2 S_{11}\right)+\left(S_{11}\right)^{2}-\left(S_{21}\right)^{2}\right\}}{\left\{\left(1-2 S_{11}\right)+\left(S_{11}\right)^{2}-\left(S_{21}\right)^{2}\right\}}\right]^{1 / 2}, \\
\text { Wave number } k_{\mathrm{wn}} & =\frac{\omega}{3 \times 10^{8} \mathrm{~m} / \mathrm{s}}, \\
\text { Slab (substrate material)thickness } & =P_{\text {slab. }}
\end{aligned}
$$

Figure 15 depicts the comparison of $S$-parameters (transmission coefficients: $S_{21}$ and reflection coefficients: $S_{11}$ ) that originate from the waveguide setup of the proposed SRR cell during the simulation as well as experimental modes. The transmission peaks are observed at resonance frequencies 2.4 and $5.8 \mathrm{GHz}$. The SRR cell exhibits the characteristics of a magnetic resonator and indicates the negative permeability nature at resonant modes $(2.4 / 5.8 \mathrm{GHz})$. This negative permeability feature is created due to the orthogonal orientation of the magnetic field. As illustrated in Figure 15, the reflection coefficient $\left(S_{11}\right.$ parameter $)$ is identified at the zero level $(<-1 \mathrm{~dB})$ and the transmission coefficient $\left(S_{21}\right.$ parameter $)$ underneath the reference level $(-10 \mathrm{~dB})$ at operating frequencies $2.4 / 5.8 \mathrm{GHz}$, which reveals the stop-band characteristics of the proposed SRR structure at these resonant frequencies. Figure 16 represents the real and imaginary part of permeability under the simulation and measurement states. The real section of permeability (Real Mue) is negative at target frequencies 2.4/5.8 GHz, which confirms the proposed SRR is a negative material consisting of the properties of metamaterial, as indicated in Figure 16. 


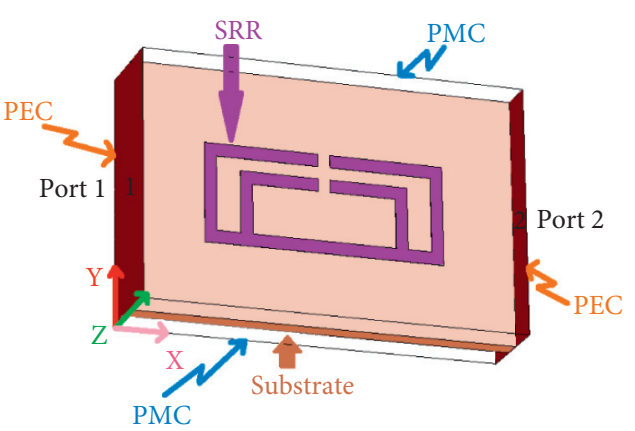

(a)

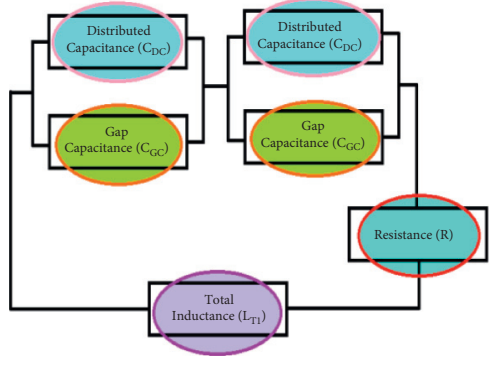

(b)

FIGURE 14: Simulated waveguide setup with an equivalent circuit model for the proposed SRR structure.

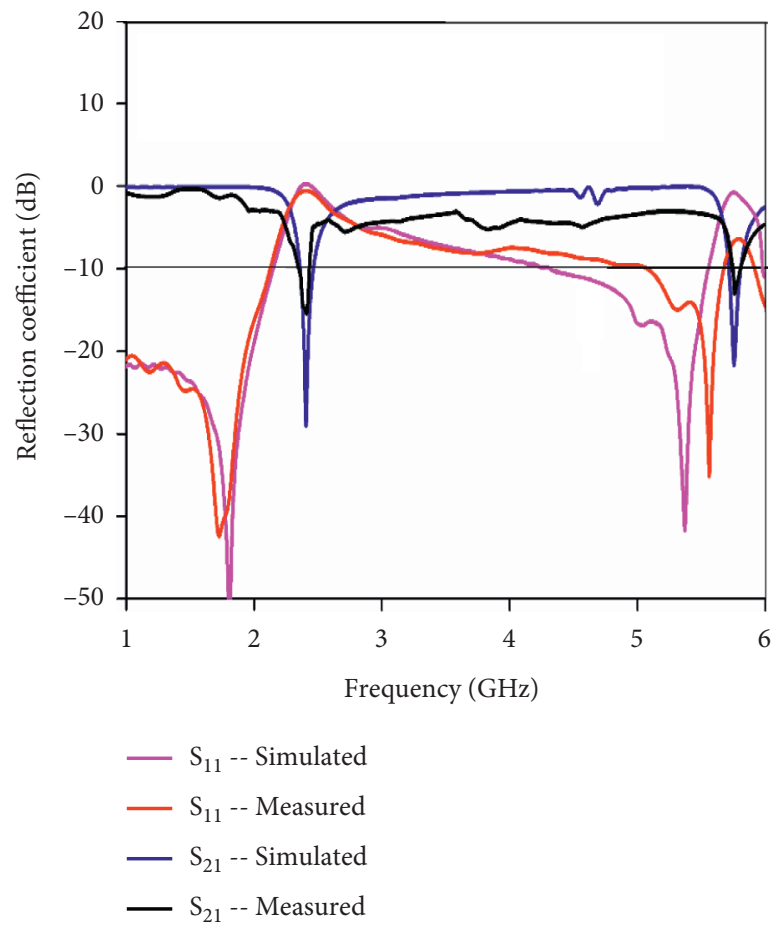

FIgURE 15: Comparison of S-parameters (transmission coefficients: $S_{21}$ and the reflection coefficients: $S_{11}$ ) during the simulation and measurement mode.

\subsection{Design Analysis of the Proposed Metamaterial Comple-} mentary Split-Ring Resonator (CSRR). This section describes the design process and analysis of the proposed complementary split-ring resonator (CSRR) unit cell in brief. The proposed CSRR structure is constructed by using two rings with split gaps opposite to each other. The dielectric material properties (permeability/permittivity characteristics) of the proposed cell are achieved with the implementation of a waveguide setup, as depicted in Figure 17. By using this setup, the S-parameters are obtained to identify the effective dielectric parameters $\left(\mu_{\mathrm{eff}}\right.$ and $\left.\varepsilon_{\text {eff }}\right)$ of the metamaterial CSRR cell. The waveguide setup is designed in the simulation mode by using a CST Microwave Studio (MWS) simulator, as indicated in Figure 17. Figure 18 represents the electrical equivalent model of the proposed CSRR cell, which works as an LC parallel tank circuit to provide the resonant operating frequency [36]. The model is designed with a parallel combination of capacitive and inductive elements. The proposed CSRR cell is placed inside the waveguide setup to obtain the experimental $S_{11}$ and $S_{21}$ values and connected with VNA.

As illustrated in Figure 17, the external magnetic $(H)$ field is applied towards the CSRR cell, which generates the EMF around the cell and is coupled across the rectangular conducting rings. The indicative effect of the proposed CSRR structure ( $\left.L_{\mathrm{MR}-\mathrm{CSRR}}\right)$ is due to the conducting strip between the slots, and the capacitive effect $\left(C_{\mathrm{MR}-\mathrm{CSRR}}\right)$ is because of the slot between the metallic strips. This arrangement creates the LC resonant environment, and the respective operating frequency $\left(f_{\text {reso-CSRR }}\right)$ is obtained by the following equations [36]: 


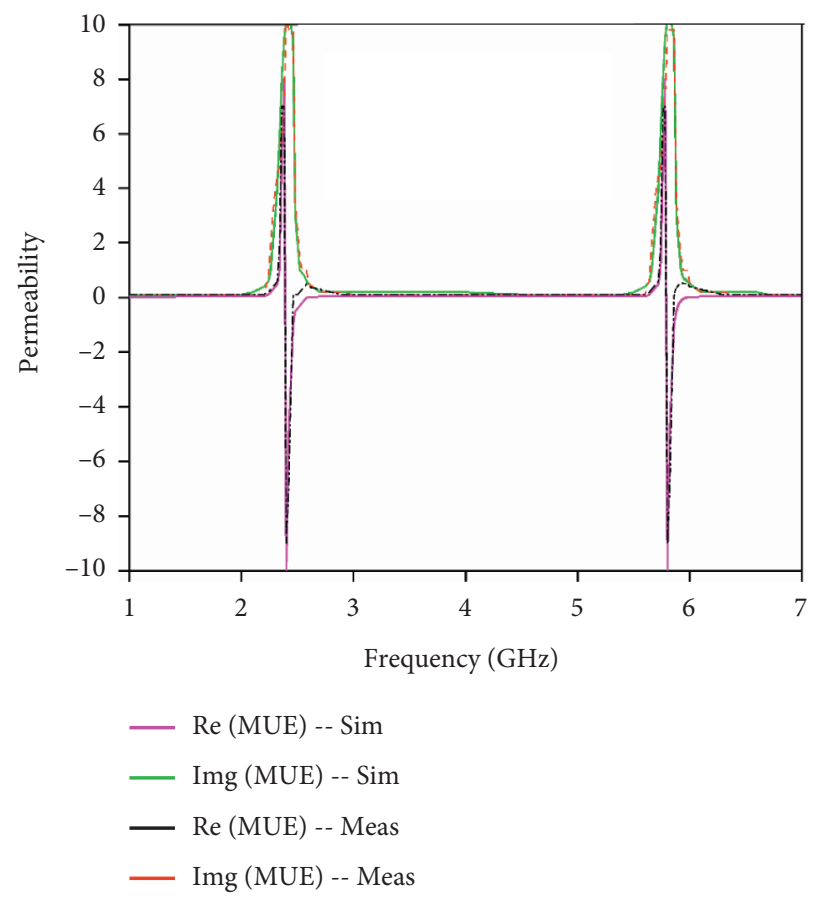

FIGURE 16: Comparison of the real and imaginary section of permeability during simulation and measurement modes.

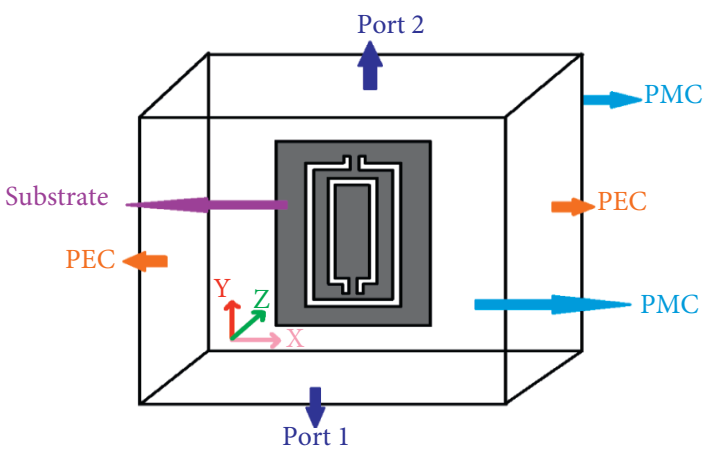

Figure 17: Proposed CSRR topology.

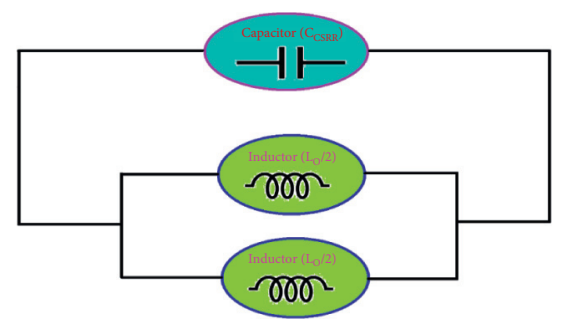

FIGURE 18: An equivalent LC parallel tank circuit model of the proposed CSRR. 


$$
\begin{aligned}
f_{\text {reso-CSRR }} & =\frac{1}{2 \pi \sqrt{L_{\mathrm{MR}-\mathrm{CSRR}} C_{\mathrm{MR}-\mathrm{CSRR}}},} \\
C_{\mathrm{MR}-\mathrm{CSRR}} & =\frac{\left(N_{R}-1\right)\left(J_{0}\right)}{2\left[\left\{2 L_{\text {Intrn-CSRR }}-\left(2 N_{R}-1\right)\left(W_{\text {Intrn-CSRR }}+g_{2}\right)\right\}\right]}, \\
J_{0} & =\left\{\frac{T\left(\sqrt{1-T^{2}}\right)}{T(t)}\right\}, \\
t & =\frac{\left(g_{2} / 2\right)}{\left\{\left(W_{\text {Intrn-CSRR }}\right)+\left(g_{2} / 2\right)\right\}}, \\
L_{\mathrm{MR}-\mathrm{CSRR}} & =4 \mu_{0}\left[\left\{L_{\text {Intrn-CSRR }}-\left(N_{R}-1\right)\right\}\left\{W_{\text {Intrn-CSRR }}+g_{2}\right\}\right]\left[\ln \left(\frac{0.98}{q}\right)+1.84 q\right], \\
q & =\left[\frac{\left\{\left(N_{R}-1\right)\left(W_{\text {Intrn-CSRR }}+g_{2}\right)\right\}}{\left.\left\{1-\left(N_{R}-1\right)\left(W_{\text {Intrn-CSRR }}+g_{2}\right)\right\}\right],}\right.
\end{aligned}
$$

where $T(t)=$ complete elliptic integral of the first kind, $N_{R}=$ number of rings associated with the proposed CSRR, $L_{\text {Intern-CSRR }}=$ length of an internal ring of CSRR, $W_{\text {Intern- }}$ $\mathrm{CSRR}=$ width of an internal ring of CSRR, and $g_{2}=$ spacing between the slots.

The CSRR cell is identical to the dual element formation of the SRR cell by the implementation of the duality principle. The proposed CSRR cell exhibits the characteristics of a pass-band filter and achieves an operating resonant frequency of $4.34 \mathrm{GHz}$. To understand the pass-band performance of the proposed CSRR, the simulated and experimental $S$-parameters (transmission coefficients: $S_{21}$ and the reflection coefficients: $S_{11}$ ) derived from the waveguide setup are compared, as depicted in Figure 19. The peak is observed at operating targeted frequency $4.34 \mathrm{GHz}$. The scattering parameters ( $S 11$ and $S 21$ ) are attained with the help of the effective medium theory [36]. During waveguide arrangement, CSRR is put inside the waveguide along the $x-y$-plane with the implementation of the boundary conditions of PEC (Perfect Electric Conductor) and PMC (Perfect Magnetic Conductor), as indicated in Figure 17. The proposed CSRR is excited by the applied EM wave through the input port, and the transmission (S21) and reflection (S11) coefficients are measured at the output port of the waveguide with the help of VNA.

The CSRR structure reveals the characteristics of the magnetic resonator and indicates the negative permeability nature at resonant modes at $4.34 \mathrm{GHz}$. This negative permittivity feature is created due to the orthogonal orientation of the electric field. As illustrated in Figure 19, the transmission coefficient ( $S_{21}$ parameter) is identified at the zero level $(<-1 \mathrm{~dB})$ and the reflection coefficient $\left(S_{11}\right.$ parameter $)$ underneath the reference level $(-10 \mathrm{~dB})$ at operating frequencies $4.34 \mathrm{GHz}$, which reveals the pass-band characteristics of the proposed CSRR structure at the respective resonant frequency. Figure 20 represents the real and imaginary part of permittivity under the simulation and measurement conditions. The real section of permittivity (real epsilon) is negative at target frequencies $4.34 \mathrm{GHz}$, which confirms that the proposed CSRR exhibits the properties of metamaterial (negative permittivity characteristics), as indicated in Figure 20.

\section{Results and Discussion}

The vector current distribution of the proposed metamaterial-inspired multiband antenna is observed for IoT applications at wireless communication modes 2.4/4.3/5.8/ $8.5 / 11.1 / 13.9 / 16.1 / 18.9 \mathrm{GHz}$ under the simulation process, as projected in Figure 21. It is noticed that the vector current strength is improved across the boundary of the proposed SRR structure at the ground plane regarding lower wireless standards (WLAN 2.4 GHz, IEEE $802.11 \mathrm{~b}$, and C-band WLAN $5.8 \mathrm{GHz}$ ). In another lower resonance frequency state (lower C-band- $4.3 \mathrm{GHz}$ ), current vectors prominently exist around the surface of the CSRR cell present inside the trapezoidal shape feedline. For higher-operating-frequency wireless communication bands at resonant modes of 8.5 , $11.1,13.9$, and $16.1 \mathrm{GHz}$, the surface vector formation is maximally present around the rectangular and S-shaped slot on the ground plane and slotted octagonal-shape radiating section. It is also identified that the vector current distribution is extremely observed near the surface of the slotted radiating part as well as CSRR structure for the lower K-band (radar communication application-18.9 GHz) wireless communication mode with enriched impedance matching. The vector is in the minutest form across the edges of the CSRR cell and slotted radiating section indicating the enhanced performance of the proposed antenna regarding radiation characteristics. For the higher resonating states (above $7 \mathrm{GHz}$ ), the vector current is uniformly allocated around the radiating part of the proposed design, which confirms the optimized impedance matching with broader bandwidth. 


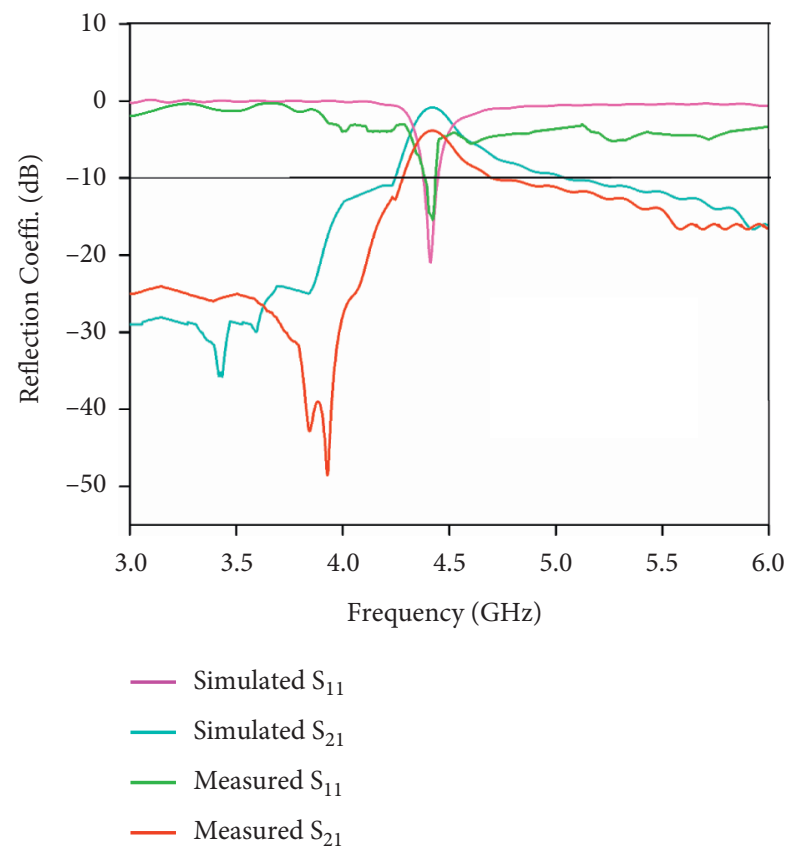

FIgURE 19: The simulated S-parameters of the proposed CSRR.

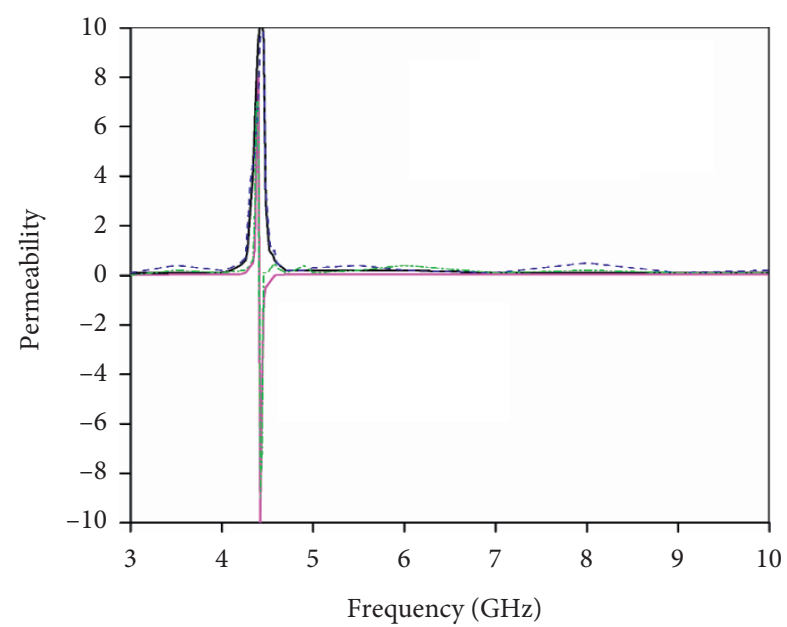

$$
\begin{aligned}
& \text { — Sim : Re (Mue) } \\
& \text { — Sim : Img (Mue) } \\
& \text { — Exp : Re (Mue) } \\
& \text { — Exp : Img (Mue) }
\end{aligned}
$$

FIGURE 20: Extracted negative permittivity of the proposed CSRR at $4.34 \mathrm{GHz}$.

Figure 22 depicts the simulated and experimental peak gain graph of the proposed antenna design. The antenna achieves the simulated and measured gain values 2.31/2.67/ 2.98/2.49/3.84/2.29/3.61/4.23 and $1.98 / 2.01 / 2.67 / 2.12 / 2.98 /$ 1.98/3.08/3.84 at resonant modes and 2.4/4.3/5.8/8.5/11.1/ 13.9/16.1/18.9 GHz, respectively. The simulated and measured radiation efficiency plots are observed in Figure 23. In the simulation, the proposed design has radiation efficiency 68.24/62.43/79.84/78.91/81.02/61.12/78.84/82.78 percent, and in measurements, it has 65.12/49.89/71.86/69.81/73.56/ $58.79 / 71.62 / 78.92$ percent at operating frequency $2.4 / 4.3 /$ 5.8/8.5/11.1/13.9/16.1/18.9 GHz, respectively.

The simulated and measured radiation patterns ( $E$ - and $H$-plane- co-/cross-polarization mode) are mentioned in Figure 24 and validate the agreement between simulated and measured formation. To analyze and study the radiation properties further, the designed antenna is tested in an anechoic chamber. The proposed antenna performances are tested at IoT application-based wireless resonating modes $2.42,4.34,5.81,8.45,11.02,13.98,16.12$, and $18.87 \mathrm{GHz}$. The simulated and measured results at these frequencies are stable and dipole-like/omnidirectional in nature during $E$ and $H$-plane with lower cross polarization (less than $-20 \mathrm{~dB})$, respectively. The $E$ - and $H$-plane are basically the principal planes; the $E$-plane means the plane containing the electric field, while the $H$-plane contains the magnetic field. Copolar means when the polarization of both the transmitting (test antenna) and receiving antenna (reference horn antenna) is the same, and cross polarization means when the polarization of both the antennas is different. In the proposed design, patterns indicate the higher values of copolarization as compared to the cross polarization. It means more radiation in the desired direction and less radiation in the unwanted direction. Patterns showing cross polarization below $20 \mathrm{~dB}$ prove that the proposed structure provides stable and consistent patterns as desired for resonant frequencies.

Table 4 indicates the optimality of the proposed miniaturized metamaterial-inspired frequency-band reconfigurable multiband antenna with the comparison of existing similar types of structures on the basis of various antenna parameters. It is visible from the table that the claimed antenna design is novel and superior over many designs in 

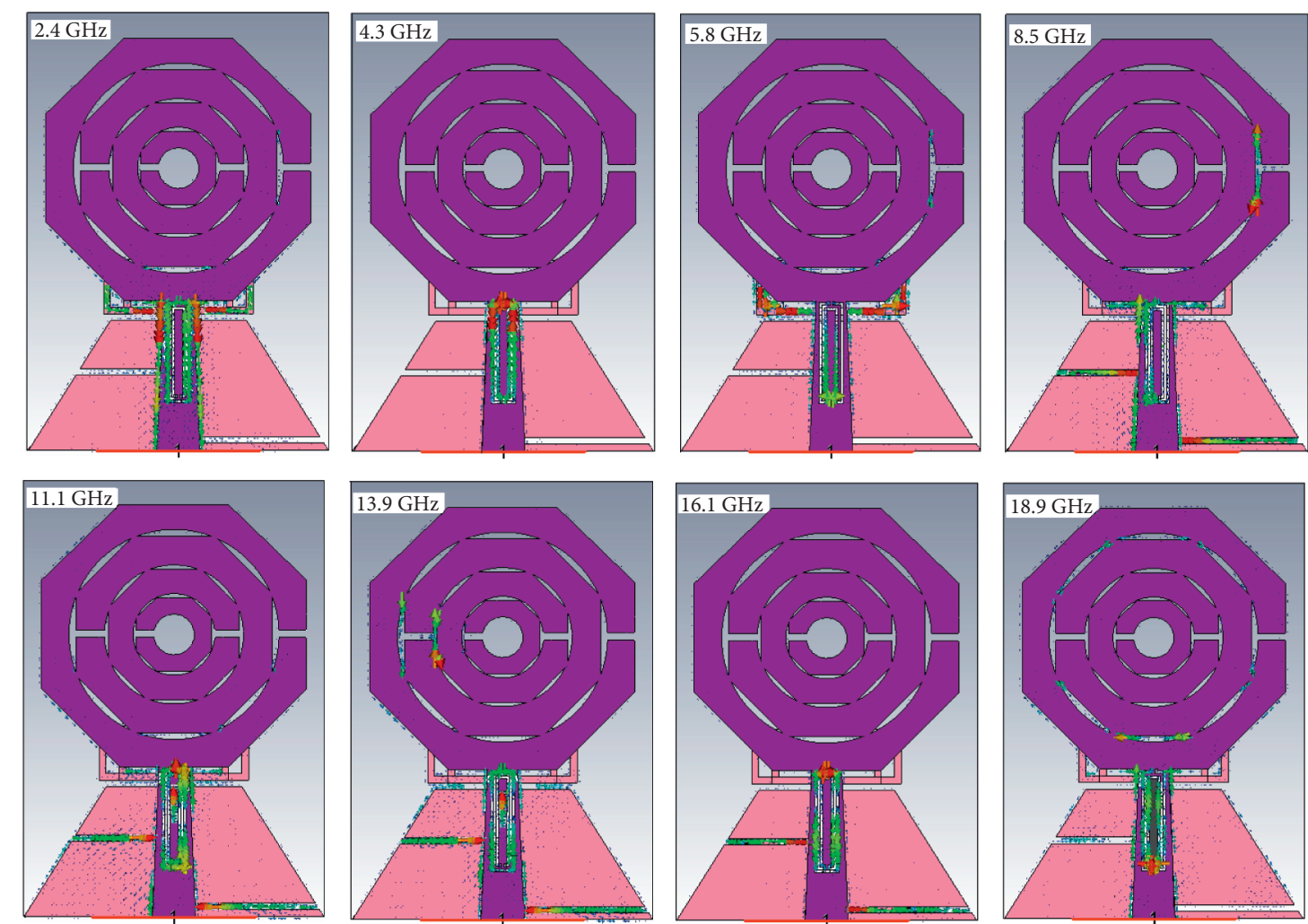

${ }_{\mathrm{Z}} \stackrel{\mathrm{Y}}{\Rightarrow}$

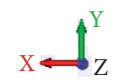

Figure 21: Vector current distribution for the multiband antenna design at 2.4/4.3/5.8/8.5/11.1/13.9/16.1/18.9 GHz under the simulation process.

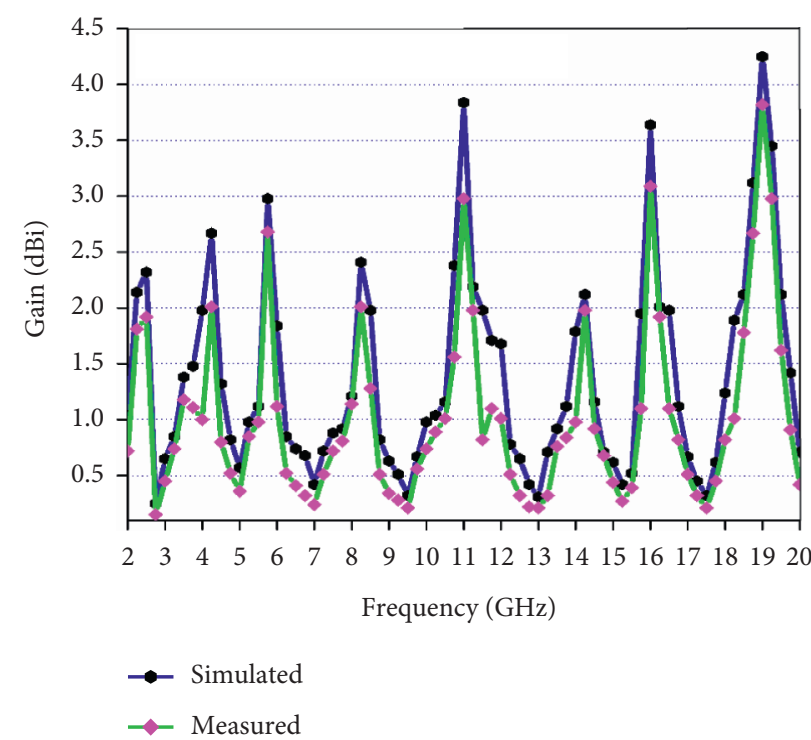

FIGURE 22: Comparative graphs of antenna peak gain in the simulated and experimental mode. 


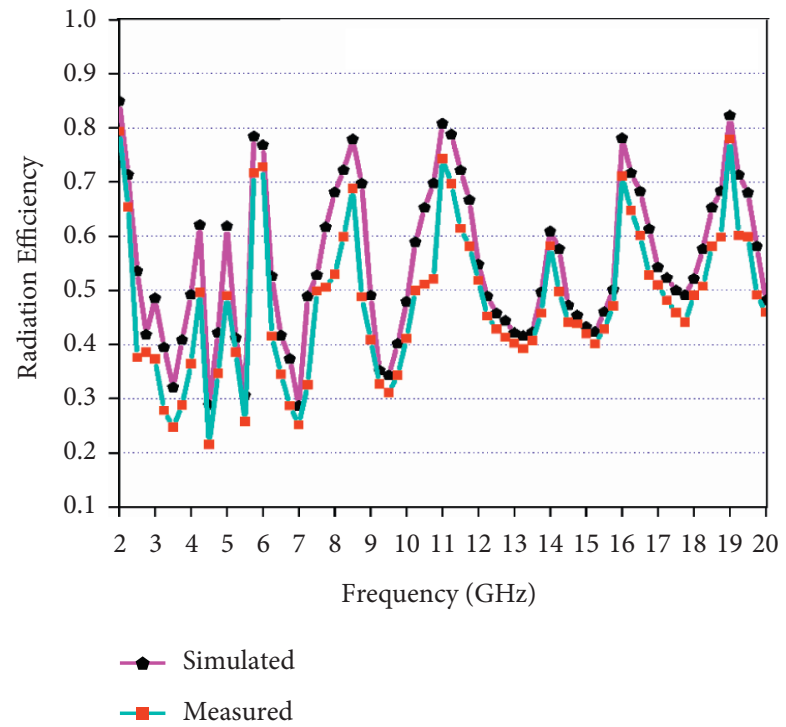

FIGURE 23: Comparative graphs of antenna radiation efficiency in simulated and measurement states.
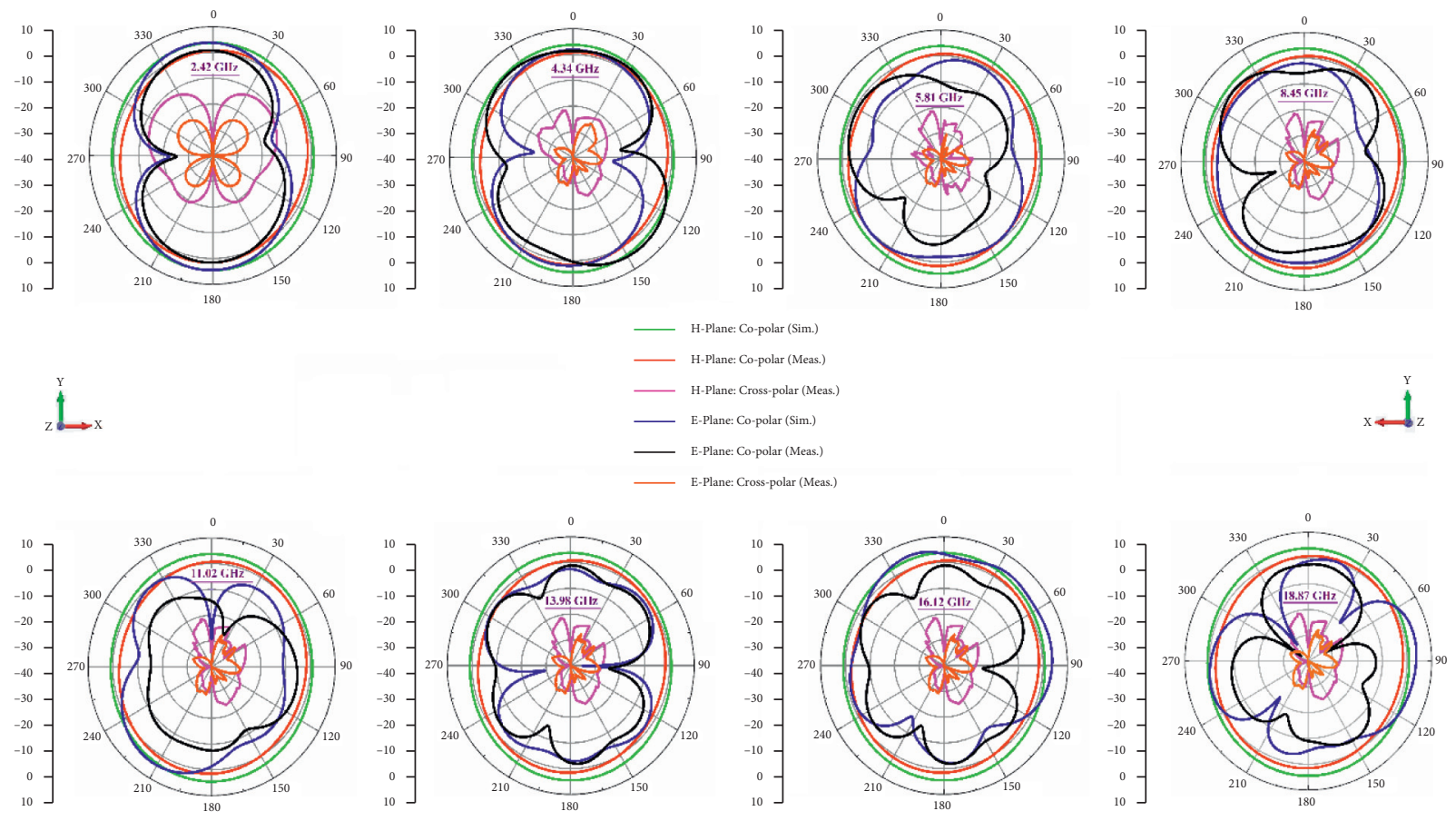

FIGURe 24: Patterns (Sim. and Meas.) at 2.42/4.34/5.81/8.45/11.02/13.98/16.12/18.87 GHz.

TABLE 4: Comparison of the proposed antenna with other published relevant structures on the basis of various antenna characteristics.

\begin{tabular}{|c|c|c|c|c|c|c|c|c|}
\hline [Ref.] & Year & $\begin{array}{c}\text { Electrical length (at the } \\
\text { lowest resonant frequency, } \\
\text { GHz) }\end{array}$ & $\begin{array}{l}\text { Fractional } \\
\text { bandwidth } \\
(\%)\end{array}$ & $\begin{array}{l}\text { Gain } \\
(\mathrm{dBi})\end{array}$ & $\begin{array}{l}\text { Efficiency } \\
(\%)\end{array}$ & $\begin{array}{l}\text { Operating } \\
\text { bands/ } \\
\text { modes }\end{array}$ & $\begin{array}{c}\text { Wireless } \\
\text { applications/ } \\
\text { standards }(\mathrm{GHz})\end{array}$ & $\begin{array}{c}\text { Frequency } \\
\text { reconfigurability } \\
\text { (PIN diode) } \\
\text { approach } \\
\text { implemented }\end{array}$ \\
\hline [12] & 2013 & $\begin{array}{c}0.32 \lambda \times 0.18 \lambda \times 0.006 \lambda \\
(1.8 \mathrm{GHz})\end{array}$ & $47.27 / 38.88$ & $\begin{array}{l}-0.56 / \\
-0.62\end{array}$ & $89.2 / 98.1$ & 2 & $\begin{array}{c}\text { GPS/WLAN (1.5/ } \\
2.4)\end{array}$ & No \\
\hline [7] & 2014 & $\begin{array}{c}0.32 \lambda \times 0.32 \lambda \times 0.0128 \lambda \\
(2.4 \mathrm{GHz})\end{array}$ & $\begin{array}{c}34.48 / \\
18.28 / 19.96\end{array}$ & $\begin{array}{l}3.97 / \\
4.04 / \\
3.25\end{array}$ & - & 3 & $\begin{array}{c}\text { WLAN/WiMAX } \\
(2.4 / 3.5 / 5.8)\end{array}$ & No \\
\hline
\end{tabular}


TABle 4: Continued.

\begin{tabular}{|c|c|c|c|c|c|c|c|c|}
\hline [Ref.] & Year & $\begin{array}{l}\text { Electrical length (at the } \\
\text { lowest resonant frequency, } \\
\mathrm{GHz} \text { ) }\end{array}$ & $\begin{array}{l}\text { Fractional } \\
\text { bandwidth } \\
\quad(\%)\end{array}$ & $\begin{array}{l}\text { Gain } \\
(\mathrm{dBi})\end{array}$ & $\begin{array}{l}\text { Efficiency } \\
(\%)\end{array}$ & $\begin{array}{l}\text { Operating } \\
\text { bands/ } \\
\text { modes }\end{array}$ & $\begin{array}{c}\text { Wireless } \\
\text { applications/ } \\
\text { standards }(\mathrm{GHz})\end{array}$ & $\begin{array}{c}\text { Frequency } \\
\text { reconfigurability } \\
\text { (PIN diode) } \\
\text { approach } \\
\text { implemented }\end{array}$ \\
\hline [5] & 2015 & $\begin{array}{c}0.289 \lambda \times 0.227 \lambda \times 0.0041 \lambda \\
(1.55 \mathrm{GHz})\end{array}$ & $\begin{array}{c}5.56 / 5.86 / \\
19.34 / 13.69\end{array}$ & $\begin{array}{c}1.3 / \\
2.3 / \\
3.5 / 4.4\end{array}$ & $\begin{array}{l}76.8 / 80.1 / \\
96.6 / 85.5\end{array}$ & 4 & $\begin{array}{c}\text { GPS/WLAN/ } \\
\text { WiMAX }(1.5 / 2.4 / \\
3.5 / 5.4)\end{array}$ & No \\
\hline [13] & 2016 & $\begin{array}{c}0.26 \lambda \times 0.26 \lambda \times 0.0084 \lambda \\
(1.6 \mathrm{GHz})\end{array}$ & $\begin{array}{c}20.73 / \\
15.02 / 31.96\end{array}$ & $\begin{array}{c}1.64 / \\
2.07 / \\
4.06\end{array}$ & $\begin{array}{c}66.2 / \\
77.15 / 87.6\end{array}$ & 3 & $\begin{array}{c}\text { GPS/WLAN (1.9/ } \\
2.4 / 5)\end{array}$ & No \\
\hline [14] & 2017 & $\begin{array}{c}0.134 \lambda \times 0.158 \lambda \times 0.0112 \lambda \\
(2.1 \mathrm{GHz})\end{array}$ & $2.4 / 3.2 / 12.1$ & $\begin{array}{l}1.36 / \\
1.57 / \\
1.83\end{array}$ & - & 3 & $\begin{array}{l}\text { UMTS/WiMAX/ } \\
\text { WLAN }(2.1 / 3.45 / \\
5.43)\end{array}$ & No \\
\hline [15] & 2018 & $\begin{array}{c}0.267 \lambda \times 0.3167 \lambda \times 0.0133 \lambda \\
(2.5 \mathrm{GHz})\end{array}$ & $8 / 6 / 5 / 69.3$ & $\begin{array}{l}3.8 \\
\text { (avg. } \\
\text { gain) } \\
3.48 /\end{array}$ & $\begin{array}{l}89 \% \text { (avg. } \\
\text { rad. eff.) }\end{array}$ & 4 & $\begin{array}{l}\text { WLAN/WiMAX/ } \\
\text { ITU/X-band }(2.4 / \\
3.35 / 5.8 / 7.5)\end{array}$ & No \\
\hline [9] & 2018 & $\begin{array}{c}0.3387 \lambda \times 0.3387 \lambda \times 0.0133 \lambda \\
(2.54 \mathrm{GHz})\end{array}$ & $\begin{array}{c}15.1 / 3.45 / \\
12.59 / 3.33 / \\
3.25 / 5.4 / \\
16.58\end{array}$ & $\begin{array}{l}3.02 / \\
4.49 / \\
4.25 / \\
3.59 / \\
3.81 / 5\end{array}$ & - & 7 & $\begin{array}{c}\text { WLAN/WiMAX/ } \\
\text { PAN/OFDM }(2.54 / \\
3.48 / 4.02 / 4.34 / 5.1 / \\
5.54 / 6.24)\end{array}$ & No \\
\hline [26] & 2018 & $\begin{array}{c}0.33 \lambda \times 0.27 \lambda \times 0.01 \lambda \\
\quad(3.3 \mathrm{GHz})\end{array}$ & $\begin{array}{l}3.5 / 5.01 / \\
13.2 / 5.77\end{array}$ & $\begin{array}{c}1.35 / \\
1 / \\
1.07 / \\
1.75\end{array}$ & - & 4 & $\begin{array}{l}\text { WiMAX/X-band } \\
(3.1 / 5.52 / 7.31 / 9.72)\end{array}$ & No \\
\hline [28] & 2019 & $\begin{array}{c}0.4884 \lambda \times 0.4329 \lambda \times 0.0178 \lambda \\
(3.33 \mathrm{GHz})\end{array}$ & $\begin{array}{c}5.11 / 7.33 / \\
11.70 / 6.38 / \\
12.03 / 5.62\end{array}$ & $\begin{array}{c}2.72 / \\
3.81 / \\
2.12 / \\
2.78 / \\
3.68 / \\
4.10 \\
194 /\end{array}$ & $\begin{array}{c}41.2 / 84.7 / \\
52.8 / 69.7 / \\
78.8 / 76.9\end{array}$ & 6 & $\begin{array}{c}\text { WLAN/WiMAX/C/ } \\
\text { X/Ku-band }(3.3 / 5.0 / \\
5.8 / 6.6 / 9.9 / 15.9)\end{array}$ & Yes \\
\hline [25] & 2019 & $\begin{array}{c}0.260 \lambda \times 0.253 \lambda \times 0.0059 \lambda \\
(2.23 \mathrm{GHz})\end{array}$ & $\begin{array}{c}11.81 / 4.27 / \\
4.29 / 6.62 / \\
3.27 / 4.22 / \\
8.13\end{array}$ & $\begin{array}{c}1.94 / \\
2.2 / \\
1.66 / \\
3.87 / \\
3.65 / \\
4.06 / \\
4.14\end{array}$ & $\begin{array}{l}41.5 / 48.6 / \\
58.1 / 60.1 / \\
84.4 / 78.7 / \\
82.1\end{array}$ & 7 & $\begin{array}{l}\text { WLAN/WiMAX/C/ } \\
\text { X/Ku-band }(2.4 / 3 / \\
3.5 / 5 / 5.8 / 11.8 / 13.1)\end{array}$ & No \\
\hline [37] & 2020 & $\begin{array}{c}0.34 \lambda \times 0.26 \lambda \times 0.0187 \lambda \\
(3.5 \mathrm{GHz})\end{array}$ & $\begin{array}{c}28.48 / \\
11.32 / \\
41.33 / \\
26.82 / 6.76 / \\
8.50 / 11.79\end{array}$ & $\begin{array}{l}1.98 / \\
2.38 / \\
2.62 / \\
3.91 / \\
2.24 / \\
3.28 / \\
4.11\end{array}$ & $\begin{array}{l}51.25 / \\
54.28 / \\
59.69 / \\
67.82 / \\
72.34 / \\
79.92 / \\
81.64\end{array}$ & 7 & $\begin{array}{c}\text { S-band WiMAX/ } \\
\text { Lower C-band/C- } \\
\text { band WLAN/Lower } \\
\text { X-band/upper X- } \\
\text { band/lower Ku- } \\
\text { band/middle Ku- } \\
\text { band }(3.5 / 4.41 / 5.8 / \\
8.26 / 10.48 / 13.35 / \\
14.42)\end{array}$ & Yes \\
\hline$[38]$ & 2020 & $\begin{array}{c}0.239 \lambda \times 0.351 \lambda \times 0.0127 \lambda \\
(2.39 \mathrm{GHz})\end{array}$ & $\begin{array}{l}8.80 / 38.78 / \\
15.54 / 35.45\end{array}$ & $\begin{array}{l}2.63 / \\
2.58 / \\
2.82 / \\
2.99\end{array}$ & $\begin{array}{l}33.5 / 38.8 / \\
84.4 / 72.8\end{array}$ & 4 & $\begin{array}{l}\text { WLAN/WiMAX/ } \\
\text { WAVE/C/X-band } \\
(2.4 / 3.5 / 5.8 / 7.9)\end{array}$ & No \\
\hline [39] & 2020 & $\begin{array}{c}0.321 \lambda \times 0.321 \lambda \times 0.021 \lambda \\
(3.85 \mathrm{GHz})\end{array}$ & $\begin{array}{l}7.7 / 6.51 / \\
6.49 / 8.61 / \\
\quad 4.94\end{array}$ & $\begin{array}{l}2 / 2.9 / \\
2.5 / \\
4.42 / \\
3.01\end{array}$ & - & 5 & $\begin{array}{l}\text { IoT/WLAN/Wi- } \\
\text { Max/C-band (3.82/ } \\
4.11 / 4.48 / 4.90 / 6.04)\end{array}$ & Yes \\
\hline
\end{tabular}


TABLE 4: Continued.

\begin{tabular}{|c|c|c|c|c|c|c|c|c|}
\hline [Ref.] & Year & $\begin{array}{l}\text { Electrical length (at the } \\
\text { lowest resonant frequency, } \\
\text { GHz) }\end{array}$ & $\begin{array}{l}\text { Fractional } \\
\text { bandwidth } \\
\quad(\%)\end{array}$ & $\begin{array}{l}\text { Gain } \\
(\mathrm{dBi})\end{array}$ & $\begin{array}{l}\text { Efficiency } \\
(\%)\end{array}$ & $\begin{array}{l}\text { Operating } \\
\text { bands/ } \\
\text { modes }\end{array}$ & $\begin{array}{c}\text { Wireless } \\
\text { applications/ } \\
\text { standards }(\mathrm{GHz})\end{array}$ & $\begin{array}{c}\text { Frequency } \\
\text { reconfigurability } \\
\text { (PIN diode) } \\
\text { approach } \\
\text { implemented }\end{array}$ \\
\hline$[40]$ & 2021 & $\begin{array}{c}0.288 \lambda \times 0.256 \lambda \times 0.0128 \lambda \\
(2.4 \mathrm{GHz})\end{array}$ & $\begin{array}{c}84 / 85.32 / \\
35.45 / \\
10.79 / 15.82\end{array}$ & - & - & 5 & $\begin{array}{c}\text { LTE 2300/LTE 2500/ } \\
\text { Bluetooth/WLAN/ } \\
\text { WiMAX/ITU-band } \\
(2.4 / 4.8 / 7.8 / 11.7 / \\
16.5)\end{array}$ & No \\
\hline [41] & 2021 & $\begin{array}{c}0.4 \lambda \times 0.4 \lambda \times 0.0064 \lambda \\
(2.4 \mathrm{GHz})\end{array}$ & $\begin{array}{c}16.17 / \\
17.85 / 48.30\end{array}$ & $\begin{array}{l}5.42 / \\
6.52 / \\
7.67\end{array}$ & - & 3 & $\begin{array}{c}\text { Wi-Fi/WLAN/X- } \\
\text { band }(2.4 / 5.8 / 9.98)\end{array}$ & No \\
\hline $\begin{array}{l}\text { Proposed } \\
\text { antenna }\end{array}$ & & $\begin{array}{c}0.256 \lambda \times 0.176 \lambda \times 0.0128 \lambda \\
(2.4 \mathrm{GHz})\end{array}$ & $\begin{array}{c}18.60 / \\
16.49 / 6.47 / \\
10.79 / \\
20.43 / 4.66 / \\
10.16 / 8.67\end{array}$ & $\begin{array}{l}2.31 / \\
2.67 / \\
2.98 / \\
2.49 / \\
3.84 / \\
2.29 / \\
3.61 / \\
4.23\end{array}$ & $\begin{array}{c}68.24 / \\
62.43 / \\
79.84 / \\
78.91 / \\
81.02 / \\
61.12 / \\
78.84 / \\
81.78\end{array}$ & 8 & $\begin{array}{l}\text { IoT application-S- } \\
\text { band WLAN, WiFi, } \\
\text { bluetooth, } Z \text {-wave, } \\
\text { wireless HART, } \\
\text { WBAN/IoT } \\
\text { application-lower } \\
\text { C-band, WAIC, } \\
\text { avionic satellite } \\
\text { communication } \\
\text { transmission } \\
\text { application/C-band } \\
\text { WLAN, IEEE } \\
\text { 802.11a/lower X- } \\
\text { band, Earth } \\
\text { exploration-satellite } \\
\text { service ITU region } 2 / \\
\text { upper X-band, } \\
\text { amateur radio } \\
\text { satellite operating } \\
\text { band/lower Ku- } \\
\text { band, direct } \\
\text { broadcast satellite } \\
\text { system/upper Ku- } \\
\text { band, terrestrial } \\
\text { microwave } \\
\text { communication } \\
\text { system service/ower } \\
\text { K-band, and radar } \\
\text { communication } \\
\text { application) }(2.4 / 4.3 / \\
5.8 / 8.5 / 11.1 / 13.9 / \\
16.1 / 18.9)\end{array}$ & Yes \\
\hline
\end{tabular}

terms of various antenna characteristics. It is also useful for covering eight wireless standards over other multiband antennas.

\section{Conclusions}

A miniaturized metamaterial-loaded and slotted octaband reconfigurable antenna is proposed and presented for IoT applications for wireless standards S-band WLAN-2.4 GHz (WiFi, Bluetooth, Z-wave, Wireless HART, and WBAN)/ lower C-band-4.3 GHz (WAIC, avionic satellite communication transmission application)/C-band WLAN-5.8 GHz (IEEE 802.11a)/lower X-band-8.5 GHz (Earth exploration-satellite service ITU region 2)/upper
X-band-11.1 GHz (amateur radio satellite operating band)/ lower $\mathrm{Ku}$-band-13.9 GHz (direct broadcast satellite system)/upper $\mathrm{Ku}$-band- $16.1 \mathrm{GHz}$ (terrestrial microwave communication system service)/lower K-band-18.9 GHz (radar communication application) and wireless communication applications. The proposed design has an octagonal shape slotted radiating section loaded with a CSRR cell (placed inside the feedline) and SRR cell (employed with the slotted trapezoidal-shape ground plane) to achieve the eight operating band characteristics for wireless applications. The frequency-band reconfigurability features regarding wireless communication modes are created by placing the switching element PIN diode inside the $S$-shaped slot at the ground plane. The antenna achieves an optimum peak gain value of 
$4.23 \mathrm{dBi}$ and radiation efficiency of $82.78 \%$ at resonant frequency. The proposed design achieves the average radiation efficiency of more than $70 \%$ for all the operating resonant bands. The antenna is fabricated, and its radiation characteristics are measured. The proposed structure represents stable and consistent radiation patterns with low cross polarization (less than $-15 \mathrm{~dB}$ ), enhanced gain/radiation efficiency, and improved impedance matching at resonant wireless communication bands.

\section{Data Availability}

The data used to support the findings of this study are included within the article.

\section{Conflicts of Interest}

No potential conflicts of interest are reported by the authors.

\section{Acknowledgments}

The authors are thankful to Prof. S. K. Koul, Indian Institute of Technology, Delhi (India), for helping to avail the facilities regarding measurement work at the department of the Centre for Applied Research in Electronics (CARE).

\section{References}

[1] D. M. Nashaat Elsheakh, H. A. Elsadek, E. A.-F. Abdallah, M. F. Iskander, and H. S. El-Henawy, "Reconfigurable single and multiband inset feed microstrip patch antenna for wireless communication devices," Progress in Electromagnetics Research C, vol. 12, pp. 191-201, 2010.

[2] P. S. Bakariya, S. Dwari, M. Sarkar, and M. K. Mandal, "Proximity-coupled microstrip antenna for bluetooth, WiMAX, and WLAN applications," IEEE Antennas and Wireless Propagation Letters, vol. 14, pp. 755-758, 2015.

[3] R. Z. Wu, P. Wang, Q. Zheng, and R. P. Li, "Compact CPWfed triple-band antenna for diversity applications," Electronics Letters, vol. 51, no. 10, pp. 735-736, 2015.

[4] A. Mehdipour, A. Sebak, C. W. Trueman, and T. A. Denidni, "Compact multiband planar antenna for $2.4 / 3.5 / 5.2 / 5.8-\mathrm{GHz}$ wireless applications," IEEE Antennas and Wireless Propagation Letters, vol. 11, pp. 144-147, 2012.

[5] Y. F. Cao, S. W. Cheung, and T. I. Yuk, "A multiband slot antenna for GPS/WiMAX/WLAN systems," IEEE Transactions on Antennas and Propagation, vol. 63, no. 3, pp. 952958, 2015.

[6] R. K. Saraswat and M. Kumar, "A frequency band reconfigurable UWB antenna for high gain applications," Progress In Electromagnetics Research B, vol. 64, pp. 29-45, 2015.

[7] M. Samsuzzaman, T. Islam, N. H. Abd Rahman, M. R. I. Faruque, and J. S. Mandeep, "Compact modified Swastika shape patch antenna for WLAN/WiMAX applications," International Journal of Antennas and Propagation, vol. 2014, Article ID 825697, 8 pages, 2014.

[8] T. Ali, M. M. Khaleeq, S. Pathan, and R. C. Biradar, "A multiband antenna loaded with metamaterial and slots for GPS/WLAN/WiMAX applications," Microwave and Optical Technology Letters, vol. 60, no. 1, pp. 79-85, 2018.

[9] P. Chaurasia, B. K. Kanaujia, S. Dwari, and M. K. Khandelwal, "Design and analysis of seven-bands-slot-antenna with small frequency ratio for different wireless applications,"
International Journal of Electronics and Communications, vol. 99, pp. 100-109, 2018.

[10] U. Patel, M. Parekh, A. Desai, and T. Upadhyaya, "Wide slot tri-band antenna for wireless local area network/world-wide interoperability for microwave access applications," International Journal of Communication Systems, vol. 34, Article ID e4897, 2021.

[11] J. Zhu and G. V. Eleftheriades, "Dual-band metamaterialinspired small monopole antenna for WiFi applications," Electronics Letters, vol. 45, no. 22, pp. 1104-1106, 2009.

[12] H.-X. Xu, G.-M. Wang, Y.-Y. Lv, M.-Q. Qi, X. Gao, and S. Ge, "Multifrequency monopole antennas by loading metamaterial transmission lines with dual-shunt branch circuit," Progress in Electromagnetics Research, vol. 137, pp. 703-725, 2013.

[13] T. Alam, M. Samsuzzaman, M. R. I. Faruque, and M. T. Islam, "A metamaterial unit cell inspired antenna for mobile wireless applications," Microwave and Optical Technology Letters, vol. 58, no. 2, pp. 263-267, 2016.

[14] S. Daniel, R. Pandeeswari, and S. Raghavan, "A compact metamaterial loaded monopole antenna with offset-fed microstrip line for wireless applications," AEU-International Journal of Electronics and Communications, vol. 83, pp. 88-94, 2017.

[15] M. Venkateswara Rao, B. T. P. Madhav, T. Anilkumar, and B. Prudhvi Nadh, "Metamaterial inspired quad band circularly polarized antenna for WLAN/ISM/bluetooth/WiMAX and satellite communication applications," AEU-International Journal of Electronics and Communications, vol. 97, pp. 229-241, 2018.

[16] U. Patel and T. K. Upadhyaya, "Design and analysis of compact $\mu$-negative material loaded wideband electrically compact antenna for WLAN/WiMAX applications," Progress in Electromagnetics Research M, vol. 79, pp. 11-22, 2019.

[17] U. Patel and T. K. Upadhyaya, "Dual band planar antenna for GSM and WiMAX applications with inclusion of modified split ring resonator structure," Progress in Electromagnetics Research Letters, vol. 91, pp. 1-7, 2020.

[18] J. Anguera, C. Puente, C. Borja, and J. Soler, Fractal Shaped Antennas: A Review. Encyclopedia of RF and Microwave Engineering, Wiley Interscience, Hoboken, NJ, USA, 2005.

[19] H.-D. Chen, H.-W. Yang, and C.-Y.-D. Sim, "Single open-slot antenna for LTE/WWAN smartphone application," IEEE Transactions on Antennas and Propagation, vol. 65, no. 8, pp. 4278-4282, 2017.

[20] S. Heun Lee, Y. Lim, Y. Joong Yoon, C.-B. Hong, and H.-I. Kim, "Multiband folded slot antenna with reduced hand effect for handsets," IEEE Antennas and Wireless Propagation Letters, vol. 9, pp. 674-677, 2010.

[21] B. Yuan, Y. Cao, and G. Wang, "A miniaturized printed slot antenna for six-band operation of mobile handsets," IEEE Antennas and Wireless Propagation Letters, vol. 10, pp. 854857, 2011.

[22] S. K. Sharma, J. D. Mulchandani, D. Gupta, and R. K. Chaudhary, "Triple-band metamaterial-inspired antenna using FDTD technique for WLAN/WiMAX applications," International Journal of RF and Microwave ComputerAided Engineering, vol. 25, no. 8, pp. 688-695, 2015.

[23] T. Ali and R. C. Biradar, "A compact multiband antenna using $\lambda / 4$ rectangular stub loaded with metamaterial for IEEE 802.11N and IEEE 802.16E," Microwave and Optical Technology Letters, vol. 59, no. 5, pp. 1000-1006, 2017.

[24] J. Kukreja, D. Kumar Choudhary, and R. Kumar Chaudhary, "CPW fed miniaturized dual-band short-ended metamaterial antenna using modified split-ring resonator for wireless 
application," International Journal of RF and Microwave Computer-Aided Engineering, vol. 27, no. 8, pp. 1-7, 2017.

[25] R. K. Saraswat and M. Kumar, "A metamaterial hepta-band antenna for wireless applications with specific absorption rate reduction," International Journal of RF and Microwave Computer-Aided Engineering, vol. 29, no. 10, pp. 1-12, 2019.

[26] T. Ali, M. Saadh Aw, and R. C. Biradar, "A fractal quad-band antenna loaded with L-shaped slot and metamaterial for wireless applications," International Journal of Microwave and Wireless Technologies, vol. 10, no. 7, pp. 826-834, 2018.

[27] V. Rajeshkumar and S. Raghavan, "A compact metamaterial inspired triple band antenna for reconfigurable WLAN/ WiMAX applications," International Journal of Electronics and Communications, vol. 69, no. 1, pp. 274-280, 2015.

[28] R. K. Saraswat and M. Kumar, "A vertex-fed hexa-band frequency reconfigurable antenna for wireless applications," International Journal of $R F$ and Microwave Computer-Aided Engineering, vol. 29, no. 10, pp. 1-13, 2019.

[29] W.-C. Liu, C.-M. Wu, and Y. Dai, "Design of triple-frequency microstrip-fed monopole antenna using defected ground structure," IEEE Transactions on Antennas and Propagation, vol. 59, no. 7, pp. 2457-2463, 2011.

[30] R. K. Saraswat and M. Kumar, "Miniaturized slotted ground UWB antenna loaded with metamaterial for WLAN and WiMAX applications," Progress in Electromagnetics Research $B$, vol. 65, pp. 65-80, 2016.

[31] Computer simulation technology microwave studio (CST MWS). http://www.cst.co.

[32] Alpha Industries, "ALPHA-6355 beamlead PIN diode. Data sheet," 2014, http://www.datasheetarchive.com/ALPHA/ PINdiode6355-datasheet.html.

[33] H. Chen, J. Zhang, Y. Bai et al., "Experimental retrieval of the effective parameters of metamaterials based on a waveguide method," Optics Express, vol. 14, no. 26, pp. 12944-12949, 2006.

[34] C. Saha and J. Y. Siddiqui, "Versatile CAD formulation for estimation of the resonant frequency and magnetic polarizability of circular split ring resonators," International Journal of RF and Microwave Computer-Aided Engineering, vol. 21, no. 4, pp. 432-438, 2011.

[35] D. R. Smith, S. Schultz, P. Markoš, and C. M. Soukoulis, "Determination of effective permittivity and permeability of metamaterials from reflection and transmission coefficients," Physical Review B, vol. 65, no. 19, pp. 195104-195109, 2002.

[36] F. Bilotti, A. Toscano, L. Vegni, K. Aydin, K. B. Alici, and E. Ozbay, "Equivalent-circuit models for the design of metamaterials based on artificial magnetic inclusions," IEEE Transactions on Microwave Theory and Techniques, vol. 55, no. 12, pp. 2865-2873, 2007.

[37] R. K. Saraswat and M. Kumar, "Implementation of hybrid fractal metamaterial inspired frequency band reconfigurable multiband antenna for wireless applications," International Journal of RF and Microwave Computer-Aided Engineering, vol. 30, no. 9, pp. 1-19, 2020.

[38] R. K. Saraswat and M. Kumar, "A quad band metamaterial miniaturized antenna for wireless applications with gain enhancement," Wireless Personal Communications, vol. 114, no. 4, pp. 3595-3612, 2020.

[39] P. P. Singh, P. K. Goswami, S. K. Sharma, and G. Goswami, "Frequency reconfigurable multiband antenna for IoT applications in WLAN, Wi-Max, and C-band," Progress in Electromagnetics Research C, vol. 102, pp. 149-162, 2020.

[40] G. Bharti and J. S. Sivia, "A design of multiband nested square shaped ring fractal antenna with circular ring elements for wireless applications," Progress in Electromagnetics Research C, vol. 108, pp. 115-125, 2021.

[41] A. Kaur and P. K. Malik, "Multiband elliptical patch fractal and defected ground structures microstrip patch antenna for wireless applications," Progress in Electromagnetics Research B, vol. 91, pp. 157-173, 2021. 